Review

\title{
Metal Catalyzed Suzuki-Miyaura Cross-Coupling- Efficient Methodology for Synthesis the Natural and non-Natural biological active Molecules
}

Hira Israr 1,Shazia Kousar 2, Nasir Rasool 1,*, Gulraiz Ahmad', Muhammad Nazirul Mubin Aziz',Muhammad Nadeem Akhtar ${ }^{3}$, Noorjahan Banu Alitheen 3,*

1 Department of Chemistry, Government College University Faisalabad, Faisalabad 38000, Pakistan; hiraisrar gcuf@ymail.com (H.I.); gulchemist35@gmail.com (G.A.)

2 Department of Basic Science and Humanities, Khwaja Fareed University of Engineering and Information Technology, Rahim Yar Khan Pakistan ; shazia_hej@hotmail.com (S.K.)

3 Faculty of Industrial Sciences \& Technology, University Malaysia Pahang, LebuhrayaTunRazak 26300, Kuantan Pahang, Malaysia; muhammadnazirulmubin@gmail.com (M.N.M.A) nadeemupm@gmail.com (M.N.A)

4 Faculty of Biotechnology and Bimolecular Sciences, University Putra Malaysia, Serdang, Selangor Darul Ehsan 43400, Malaysia;

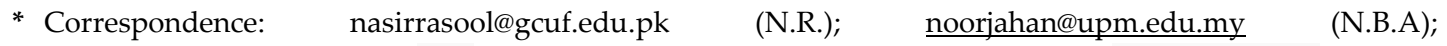
Tel.: +92-332-7491790 (N.R.); +60-3-8946-7471 (N.B.A.); Fax: +92-41-9201032 (N.R.); +60-3-8946-7510 (N.B.A.)

Abstract: New class of biologically active and non-active compounds can be synthesized via transition metal mediated Suzuki cross coupling reaction that has a great impact on the advancement of organic chemistry. These resulted products can lend a helping hand in pharmaceutical and polymer chemistry for the betterment of mankind. Suzuki-Miyaura cross coupling reaction is one of the best tools through which many natural and non-natural compounds can be synthesized.

Keywords: Palladium; Suzuki cross coupling; natural product; non-natural product;

\section{Introduction}

Transition metals mediated cross couplings have shown a new direction to the scientists for the formation of many organic compounds through the variety of chemical reactions. Palladium the most extensively employed transition metal for cross-coupling reactions and reaction rate, yield and scope depends upon the reaction partners, and the types of ligands. The Suzuki coupling is a reaction of different boronic acids with halides that is catalyzed by palladium. Mostly aryl or vinyl boronic acids and halides are used. A lot of compounds are synthesized by this methods like bi-aryl, polyolefin etc. [1]. The Suzuki coupling reaction can also be used for aromatic alkylation [2].

Suzuki-Miyaura cross-coupling is one of those couplings, which has revolutionized in the world of chemistry because of its wide use in C-C bond formation and involve oxidative addition, transmetallation and reductive elimination in the catalytic cycle. It has great advantages over other palladium-catalyzed cross-coupling reactions due to the ready availability of organoboron reagents, its inertness to water, related solvents as well as oxygen and its thermal stability, tolerance towards various functional groups and low toxicity of starting material and by-products. Suzuki reaction is more effective for the production of highly substituted styrene and other bi-aryls [3]. It has proved to be a great source for the formation of many biological active compounds. These products have paved a path to cure or to get immunity against many diseases. This review is written to explore the achievements of Suzuki coupling in the formation of natural and non-natural biological active and non-active compounds. 


\section{Literature Review}

Grasa and his co-workers investigated that the aryl chlorides or aryl triflates (1) react with arylboronic acids (2) through Suzuki coupling reaction in palladium catalyzed conditions in which ligand was N-heterocyclic carbenes which were nucleophilic in nature (scheme 1). Several substrates were employed for the investigations of the coupling reactions in the presence of $\operatorname{Pd}(0)$ or $\operatorname{Pd}(\mathrm{II})$ sources and an imidazolium salt with a base, $\mathrm{Cs}_{2} \mathrm{CO}_{3}$. System showed more reactivity than aryl chlorides that were electron-neutral and electron-rich. Fenbufen, an anti-inflammatory drug, was successfully synthesized using this general protocol and also it led to the formation of to a main intermediate in the synthesis of sartans [4].<smiles>COc1ccccc1</smiles>

1

2

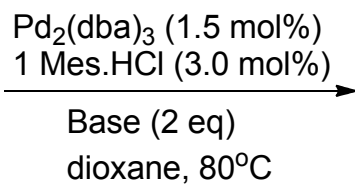<smiles>Cc1ccc(-c2ccccc2)cc1</smiles>

3

Scheme 1. 3b-acetoxy-6-iodocholest-5-ene was prepared conveniently by using cholesterol 4. This synthesized compound 5 was used as an important intermediate for the synthesis of 6- arylated cholesterol derivatives which serve as potential drugs [5].

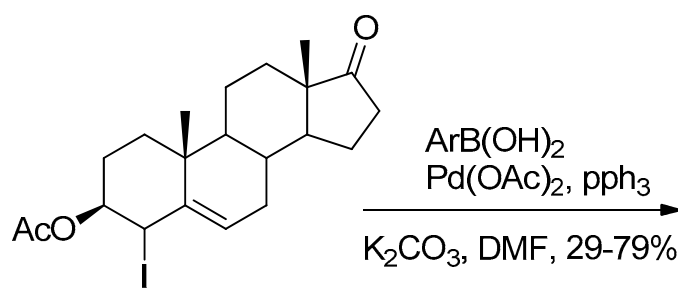

4<smiles>CC1CC(Br)=C2C[C@@H](OC3CCCC3)CC[C@]2(C)C1C</smiles>

5

Scheme 2: Synthesis of 6-aryl-substituted cholesterol derivatives.

Richardson and his colleagues also put forward the synthesis of novel 3-aryl indoles (8) as progesterone receptor antagonists. These analogs were also prepared by adopting Suzuki cross coupling reaction as a key step from 2-bromo-6-nitro indole (6) (Scheme 3) [6].

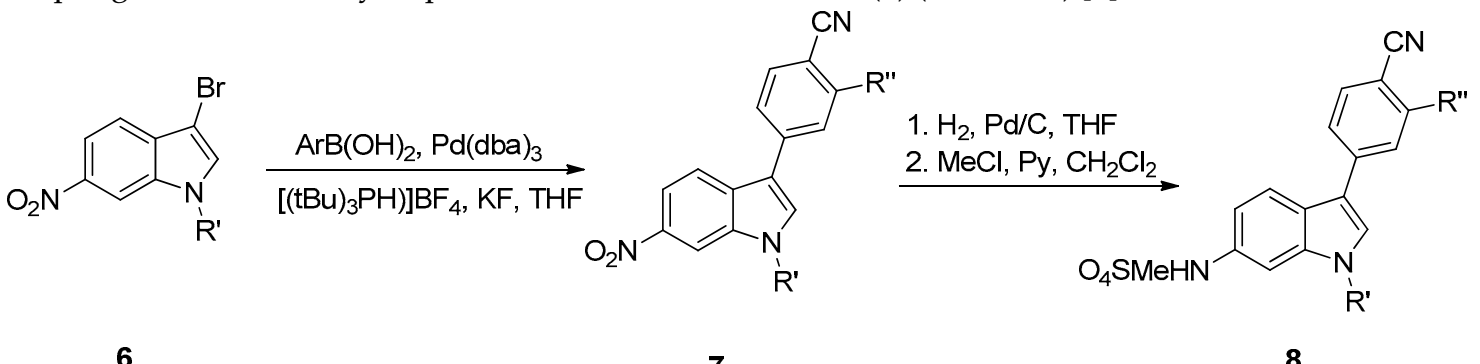

Scheme 3:Synthesis of progesterone receptor antagonists.

Suzuki-Miyaura cross-coupling reaction of 1-iodoalkenes with B-alkylboron compounds was investigated by De Clercq for the direct and stereoselective synthesis of epoxypolyenes. It allows for straightforward and convergent assembly of compounds that are structurally similar to (3S)oxidosqualene, an important intermediate in steroid biosynthesis. The starting (S)-methyloctalone 
was transformed to the dicyclohexylboron intermediate using the Grieco-Sharpless elimination protocol (Scheme 4) [7].<smiles>O=C1C=C2CCC3(CCCC3C2)OCCO1</smiles>

9

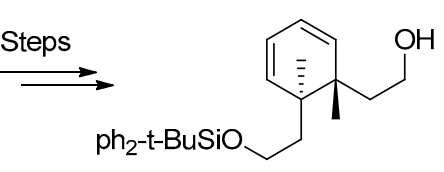

10

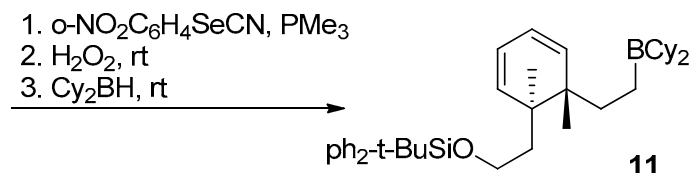

11

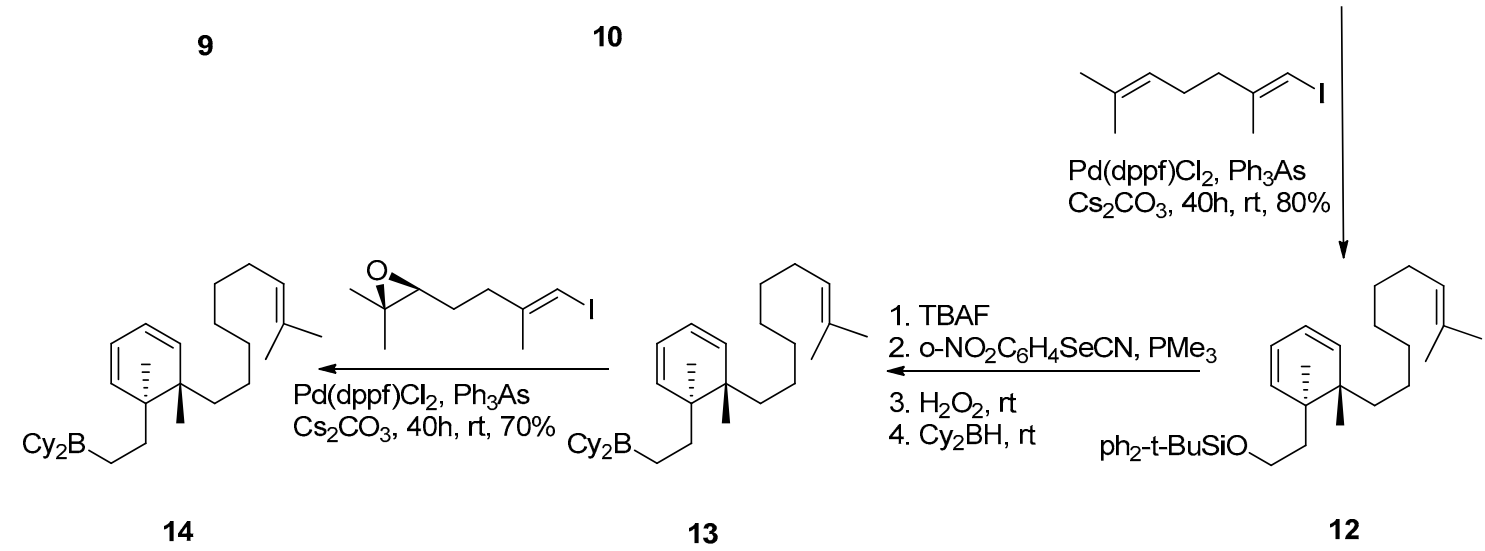

Scheme 4:Synthesis of the (3S)-oxidosqualene analog.

Coumarin-based compounds and their derivatives have proved reasonable anticancer therapeutic agents. Its derivatives have been synthesized by adopting Suzuki cross coupling reaction followed by Heck reaction. 4-methoxy (hydroxy) phenyl and 4-methoxy(hydroxyl)styryl groups were introduced at C3 position of the 4-methylcoumarin. Compound 15 underwent a Suzuki coupling reacting with 4-methoxyphenylboronic acid, palladium acetate, potassium hydrogen phosphate to afford compound 16, whereas, through Heck coupling reacting with 4-methoxy styrene and palladium chloride, gave compound 17. Finally, carrying out onto the methoxy derivatives 16 and 17 a cleavage with boron tribromide 18and 19, respectively, were obtained (Scheme 5) [8]. 


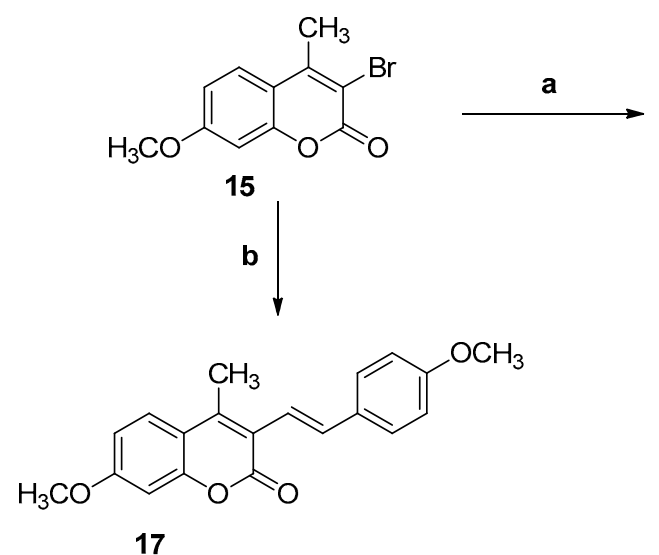

17

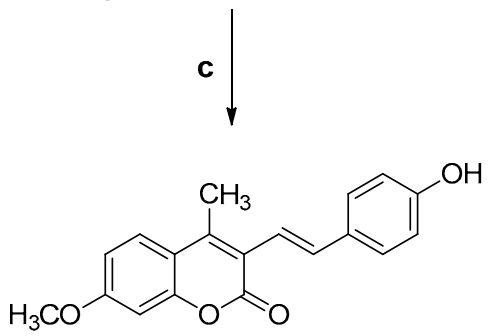<smiles>COc1ccc(-c2c(C)c3ccc(OC)cc3oc2=O)cc1</smiles><smiles>Cc1c(-c2ccc(O)cc2)c(=O)oc2cc(O)ccc12</smiles>

18

19

Scheme 5. Reagents and conditions: (a) $p$-MeO-Ph-boronic acid, $\mathrm{K}_{2} \mathrm{HPO}_{4}, \mathrm{Pd}(\mathrm{OAc})_{2}$, $\mathrm{MeOH}, 60{ }^{\circ} \mathrm{C}, 2 \mathrm{~h}, 85 \%$; (b) $p$-MeO-styrene, $\mathrm{PdCl}_{2}$, Et $3 \mathrm{~N}$, reflux, 12 h, 78\%; (c) $\mathrm{BBr}_{3}, \mathrm{CH}_{2} \mathrm{Cl}_{2},-20{ }^{\circ} \mathrm{C}$, overnight, $70 \%$.

Thiophenes derivaties are valuable building blocks for many natural and non-natural products and show potential applications in the flavour and pharmaceutical industries along with materials science. More specifically, polythiophenes exhibit interesting electric and non-linear optical properties. Substituted thiophenes can be synthesized by adopting the scheme involving Suzuki cross coupling. Morgado and co-workers reported series of novel alternating polymers of the type A-altB, where A is 9, 9-bis (20-ethylhexyl)fluorene and B is an extended thiophene- based moiety, via a Pd-catalyzed SM cross-coupling reaction. 2,3-Dibromothiophene(20) underwent a regioselective $\mathrm{Pd}(0)$ - catalyzed SM cross-coupling reaction at the C-2 position with different boronic acids (Scheme 6) $[9]$.

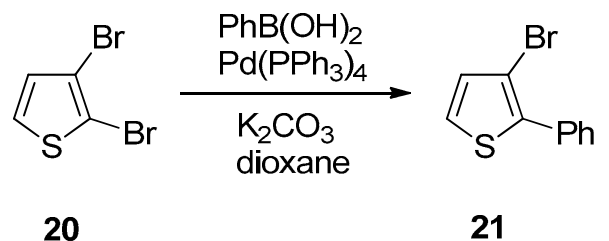

\section{Scheme 6. SM cross-coupling reaction of 2,3-Dibromothiophene}

Dendrimers are macromolecules exhibiting a perfect regularity throughout the structure. They have well-defined branched architecture. They are useful in drug delivery systems. They act as a vehicle to transport drug molecules to the required or desired site. They are also very important entities in materials chemistry, polymers and energy transfer systems. Here some recent advances in the synthesis of dendrimers has been reported that are synthesized by adopting Suzuki cross coupling. Kimura and co-workers reported 1,3,5-phenylene-based metallodendrimers containing a $\mathrm{Ru}(\mathrm{II})$ complex located at an interior core of 24 by using the $\mathrm{Pd}\left(\mathrm{PPh}_{3}\right)_{4}$-catalysed Suzuki-Miyaura 
cross-coupling reaction of the preformed dendron boronic acid with 3,8-dibromo-1,10phenanthroline 22 to give 23 , which on treatment with $\mathrm{RuCl}_{2}(\text { bipy })_{2}$ resulted in the formation of 24 (Scheme 7) [10].

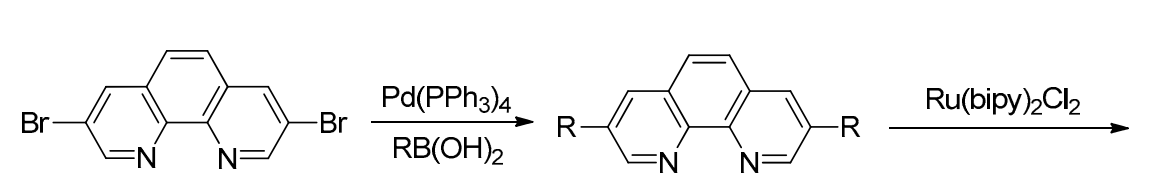

22
23

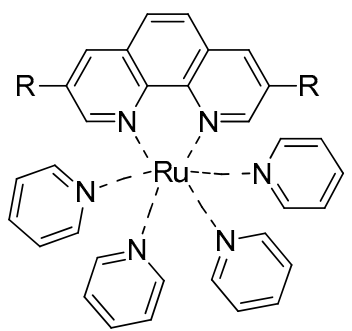

24

Scheme 7. Dendrimer synthesis via the SM cross-coupling

Danion et al. have reported that protected vinylboronic $\alpha$-amino acids such as 25 readily undergo the SM cross-coupling reaction with aromatic or vinyl bromides (Scheme 8) [11].

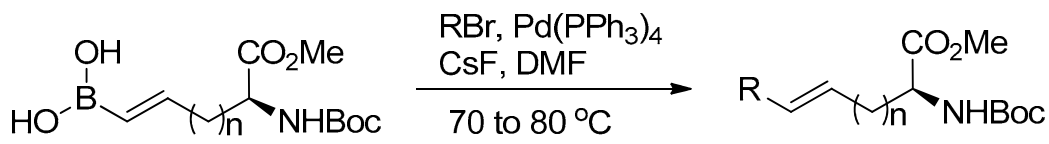

25

26

Scheme 8. Many biologically active peptides contain Phenylalanine (Phe) as an important structural component. There are several examples in the literature which show that, when Phe is replaced by various constrained analogues, the resulting peptides show enhanced biological activity and pronounced proteolytic stability. In this regard, the indanes, dibenzylglycine derivatives and tetralinbased $\alpha$-amino acids that are constrained analogues of Phe are important synthetic targets. In this respect, Kotha and co-workers realized that the SM cross-coupling reaction is useful to generate various unusual $\alpha$-amino acid derivatives. Towards this goal, the preparation of indane-based $\alpha$ amino acid derivatives was undertaken and the key $\alpha$-amino acid derivative $\mathbf{2 8}$ was prepared (Scheme 9) [12].<smiles>Cc1cc(I)c(I)cc1C</smiles>

27

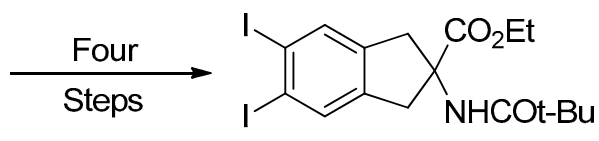

28<smiles>CCOC(=O)NC1(C(=O)OCC)Cc2cc(Br)c(Br)cc2C1</smiles>

29

(i) $\mathrm{ArB}(\mathrm{OH}) 2, \mathrm{Pd}(\mathrm{PPh} 3) 4$, aq. $\mathrm{Na}_{2} \mathrm{CO}_{3}, \mathrm{THF} /$ toluene $(1: 1), 80^{\circ} \mathrm{C}$.

Scheme 9. Synthesis of $\alpha$-amino acid derivatives.

The 4-aryltetrahydropyridine unit 33 exhibits vast biologically active entities and therapeutic agents. This specialty gives this unit unique characteristics and makes this important synthetic target. Eastwood has described a simple preparation of the cyclic vinyl boronates 32 derived from the vinyl triflate of the N-protected tetrahydropyridines. Suzuki-Miyaura cross-coupling of the boronate $\mathbf{3 1}$ with aryl bromides, iodides and triflates $\mathbf{3 0}$ which acted as a starting step proceeded in good yield to give the 4-aryl tetrahydropyridines 33 (Scheme 10). 
6 of 31

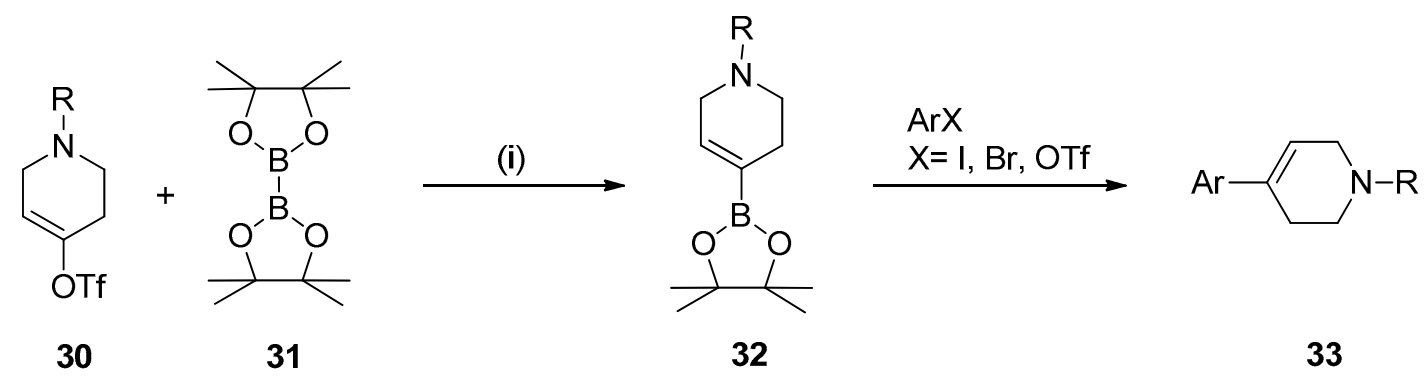

(i) $\operatorname{Ar}\left(\mathrm{B}(\mathrm{OH})_{2}, \mathrm{Pd}\left(\mathrm{PPh}_{3}\right)_{4}\right.$, eq. $\mathrm{Na}_{2} \mathrm{CO}_{3}$, THF/Toluene (1:1), $80^{\circ} \mathrm{C}$

Scheme 10: Suzuki-Miyaura cross-coupling of the boronate with aryl bromides, iodides and triflates.

Pd-catalysed cross-coupling reaction of B-alkyl-9-BBN derivatives (34) and the bromopyridines (35) have served to be a new protocol for the synthesis of biologically active compounds. The reaction can tolerate a variety of functional groups in the reaction partners and therefore provides a convenient choice for the preparation of biologically active and pharmaceutically pertinent alkyl pyridines [13].

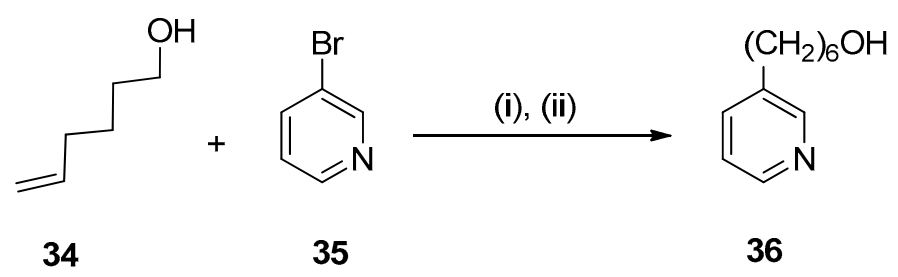

(i) 9-BBN, THF, (ii) $\mathrm{Pd}\left(\mathrm{PPh}_{3}\right)_{4}, \mathrm{~K}_{2} \mathrm{CO}_{3}, \mathrm{H}_{2} \mathrm{O}, \mathrm{DMF}, 65^{\circ} \mathrm{C}$

Scheme 11: Preparation of biologically active pyridines via SM cross coupling.

In 1999, Hudlicky and his co-workers reported the synthesis of an antitumour alkaloid, narciclasin 40, by using a Pd-catalysed SM cross-coupling reaction of the dibromo derivative 38 with the boronic acid 37 to give the key intermediate 39 , followed by a sequential transformation with $20 \%$ overall yield and with $30 \%$ yield of the coupling step [14].

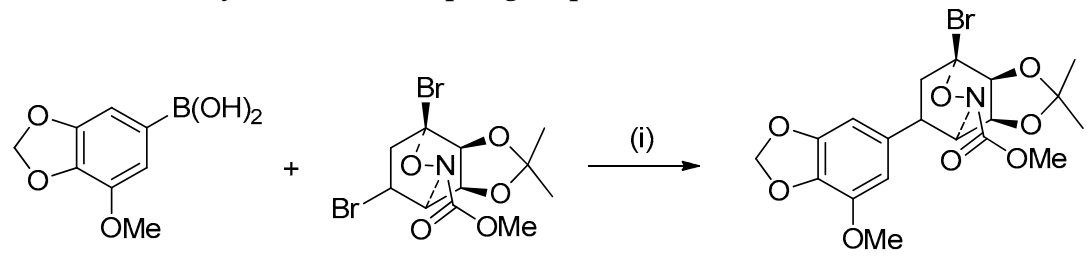

37

38

39<smiles>O=C1NC2C(=CC(O)C(O)C2O)c2cc3c(c(O)c2O1)OCO3</smiles>

40

(i) $\mathrm{Pd}\left(\mathrm{PPh}_{3}\right)_{4}$, aq. $\mathrm{Na}_{2} \mathrm{CO}_{3}$, toluene, reflux, $30 \%$

Scheme 12: synthesis of an antitumour alkaloid, narciclasin 
The compounds 44 and 45 act as endothelin (ET-1) receptor antagonists and are useful drug molecules for treating hypertension and other cardiovascular diseases. Pridgen $e t$ al. reported the $\mathrm{PdCl}_{2}(\mathrm{dppf})$-catalyzed SM cross-coupling reaction of the chiral enol ethers $\mathbf{4 1}$ with the boronic acids 42 to furnish the indene derivatives 43 in $90 \%$ ee which can be transformed into 44 and 45 by further functional group transformations [15].

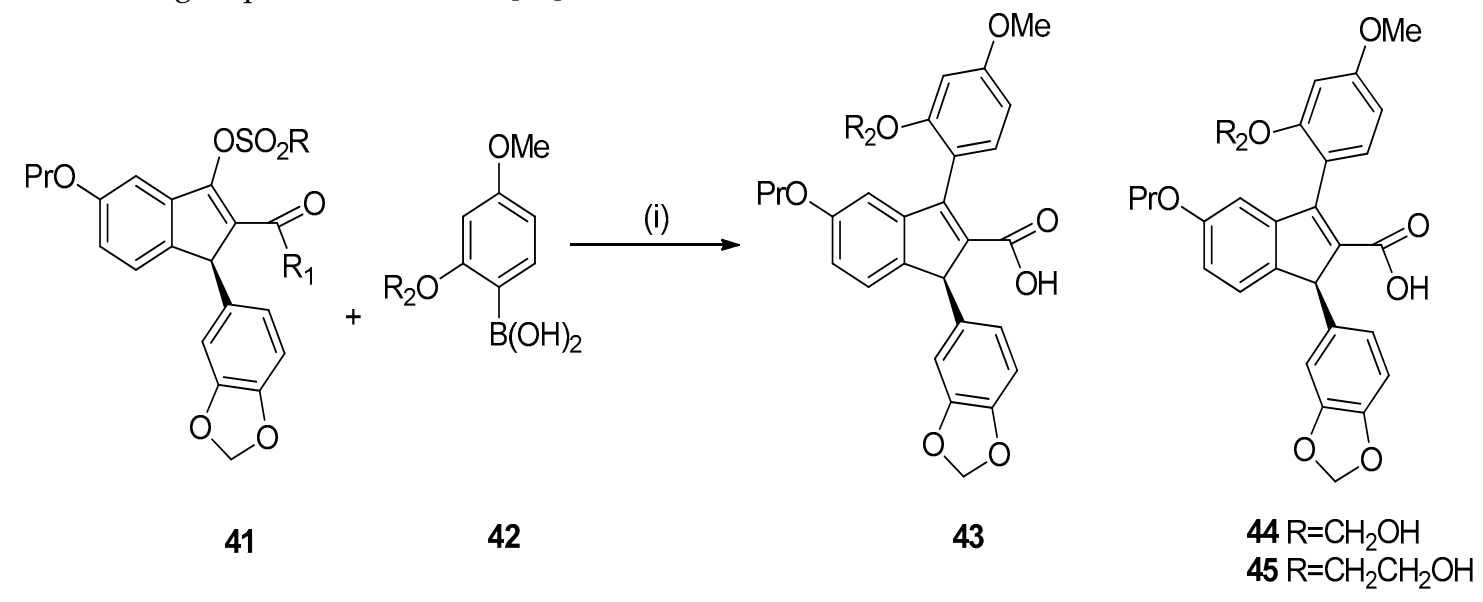

(i) $\mathrm{PdCl}_{2}$ (dppf) (5 mol\%), aq. $\mathrm{K}_{2} \mathrm{CO}_{3}$, toluene/acetone/water, $70^{\circ} \mathrm{C}, 50-98 \%$

Scheme 13: $\mathrm{PdCl}_{2}(\mathrm{dppf})$-catalyzed SM cross-coupling reaction of the chiral enol ethers.

A key biaryl system 48 for protease inhibitors such as 49 and 50 was prepared by Ma and Wu from a ligandless $\mathrm{Pd}(\mathrm{OAc})_{2}$-catalysed SM coupling reaction of 7-iodoisatin 46 with the satirically hindered arylboronic acid 47 . They found up to $70 \%$ yield when KF was used as the base and methanol as the solvent (Scheme 14) [16].

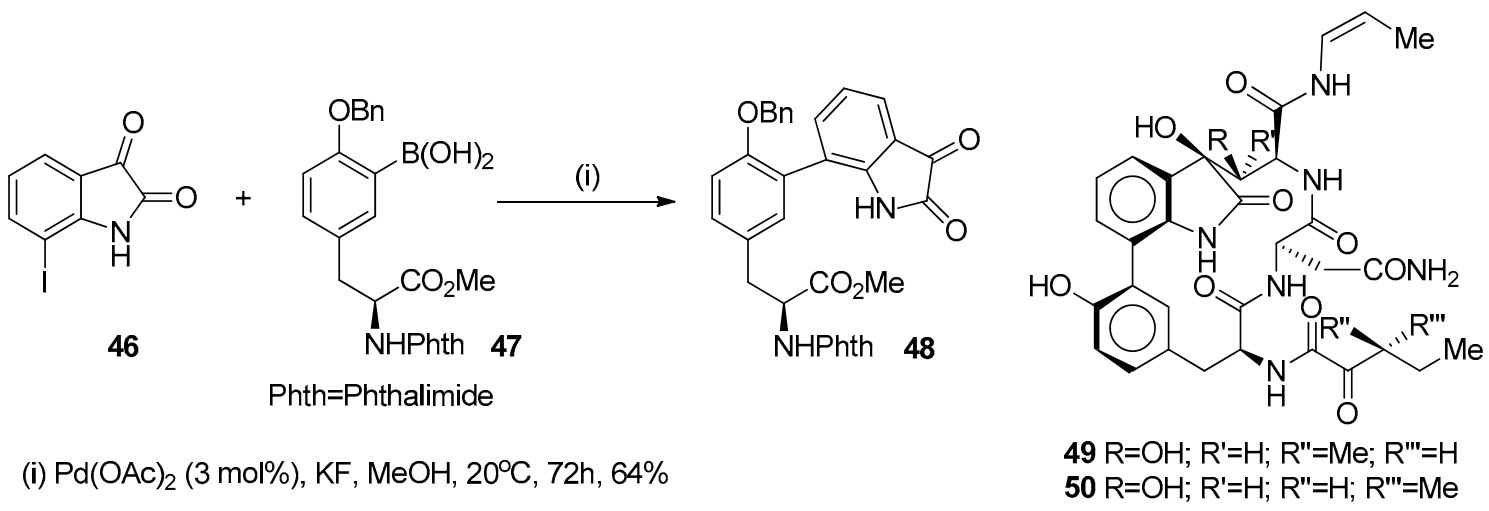

Scheme 14: Ligandless $\mathrm{Pd}(\mathrm{OAc})_{2}$-catalysed $\mathrm{SM}$ coupling reaction of 7-iodoisatin.

Phlorizin (a b-arylglucoside) is a useful drug molecule for the treatment of diabetes-related diseases, but it encounters a problem that it metabolizes very soon into the less active compound, phloretin. As a solution to this problem, Link et al. have reported an efficient method for the preparation of the phlorizin-related molecules by the hydroboration of the exo-glycal $\mathbf{5 1}$ followed by a cross-coupling reaction with the corresponding bromo and triflate derivatives 52 under $\mathrm{PdCl}_{2}(\mathrm{dppf}) \cdot \mathrm{CH}_{2} \mathrm{Cl}_{2}$ catalytic conditions to yield the b-C-glycoside 53 [17]. 


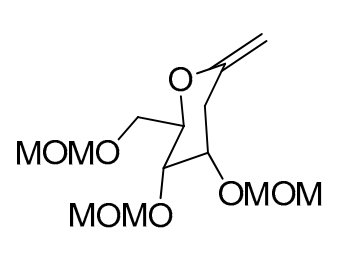

51

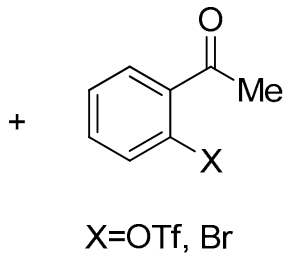

52

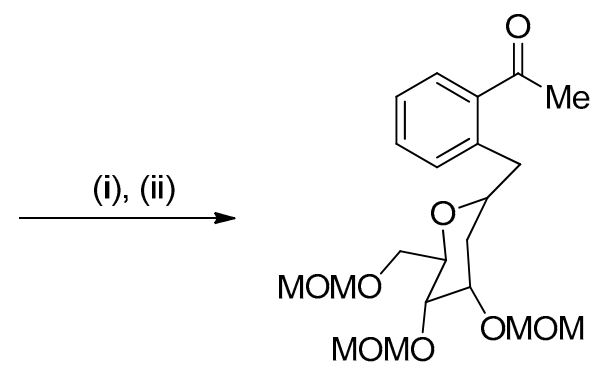

53

(i) 9-BBN, THF, reflux, 5h

(ii) $\mathrm{PdCl}_{2}$ (dppf), $\mathrm{CH}_{2} \mathrm{Cl}_{2}, \mathrm{~K}_{3} \mathrm{PO}_{4}, \mathrm{DMF}, \mathrm{H}_{2} \mathrm{O}, \mathrm{RT}, 18 \mathrm{~h}, 55 \%$

Scheme 15: Preparation of the phlorizin-related molecules by the hydroboration of the exo-glycal.

Gooßen has synthesized a variety of arylpropionic acid derivatives such as 56, which are the most important constituents of many anti-inflammatory drugs. He adopted the $\mathrm{Pd}(\mathrm{OAc})_{2}$-catalysed Suzuki-Miyaura cross-coupling reaction and utilized arylboronic acids and pinacolboronates with abromoesters in the presence of phosphine ligands and a base as shown in the following scheme 16 [18].<smiles>Cc1ccccc1Br</smiles>

54<smiles>CCOC(=O)CBr</smiles>

55<smiles>CCOC(=O)Cc1ccccc1C</smiles>

56

(i) $\mathrm{Pd}(\mathrm{OAc})_{2}(3 \mathrm{~mol} \%), \mathrm{P}(\mathrm{Nap})_{3}(9 \mathrm{~mol} \%), \mathrm{K}_{3} \mathrm{PO}_{4}, \mathrm{THF} / \mathrm{H}_{2} \mathrm{O}, \mathrm{RT}, 16 \mathrm{~h}, 90 \%$

Scheme 16: Synthesis of arylpropionic acid derivative.

Because of the great potential of quinoline derivatives as antimalarial, anti-inflammatory and antihypertensive agents, their importance has been increasing in medicinal sciences. Scientists have taking continue interest in the synthesis of quinoline derivatives substituted with a primary amino group at the 4-position. 4-Amino-2-arylquinolines have also been found to represent a novel class of NR1/2B subtype selective N-methyl-D-aspartate (NMDA) receptor antagonists. Ortho substitution of the arylamino group was also found to impart small but significant improvements in biological activity by influencing the aryl ring to twist further out of the plane of the quinoline framework. The 2-aryl-3-iodo-4-(phenylamino)quinolines undergo one-pot palladium-mediated $\mathrm{CeI}$ and $\mathrm{CeH}$ bond activation and subsequent Suzuki-Miyaura cross-coupling with arylboronic acids under anhydrous conditions to afford mixture of 2,3-diaryl-4-(phenylamino)quinolines (minor) and 2-aryl-4-([(1,10biaryl)-2-yl]amino)quinoline derivatives (major). The 2,3-diaryl-4-(phenylamino)quinolines were isolated as major products when $2 \mathrm{M} \mathrm{K}_{2} \mathrm{CO}_{3}$ was used as a base.(Shown in scheme17). A plausible mechanism, which implicates a six-membered palladacycle intermediate is proposed for the formation of the observed mixture of products. The prepared compounds were characterized using a combination of spectroscopic and X-ray crystallographic techniques [19]. 
<smiles>[R]Cc1nc2ccccc2c(Nc2ccccc2[R])c1[R]</smiles>

i) $\mathrm{ArB}(\mathrm{OH})_{2}(1.2 \mathrm{eq}), 5 \% \mathrm{Pd}\left(\mathrm{PPh}_{3}\right)_{4}, 2 \mathrm{M} \mathrm{K}_{2} \mathrm{CO}_{3}, \mathrm{DMF}, 80^{\circ} \mathrm{C}, 18 \mathrm{~h}$.

Scheme 17: Synthesis of quinoline derivatives

Thiazole is among the most significant moieties in many natural products and synthetic molecules with potent biological activities. During the past decades, natural and synthetic thiazole-based molecules have drawn increasing attentions and interests due to their miscellaneous applications in pharmaceutical sciences and material chemistry. During the last few decades, major progress has been achieved in transition-metal-catalyzed $\mathrm{C}-\mathrm{C}$ bond-formation where one or both of the carbon atoms are required to be pre-activated, such as Mizoroki-Heck reaction and Suzuki-Miyaura coupling. More recently, direct C-C bond formation via palladium (II) catalyzed C-H bond cleavage of both substrates has been becoming an exceedingly valuable process in contemporary organic synthesis, allowing concise and economical routes to be applied to the preparation of natural or synthetic compounds with biological activities. In light of the advances in this area, several groups have independently reported the cross-coupling reactions of thiazoles at 5-postionwith organic halides or acrylates. With the established condition in hand, a series of thiazole-4-carboxylates (60) were examined to demonstrate the substrate scope. Generally, all substrates reacted smoothly to provide the desired cross-coupling products in moderate to excellent yields within $48 \mathrm{~h}$. Different substitutions on the thiazole ring were well tolerated, and some patterns were observed. For 2-phenyl substrates, the substrates with electron-donating group and halogen on the benzene ring afforded the product in good yield, while the ones with electron-withdrawing substituents gave the moderate yields due to incomplete consumption of the substrates. Only trace amount of the homocoupling byproducts could be observed for all 2-phenyl substrates, while more homocoupling byproducts for 2-alkyl and 2-carbonyl substituted substrates were obtained (Scheme 18), leading to the relatively lower yields of the corresponding cross-coupling products [20].

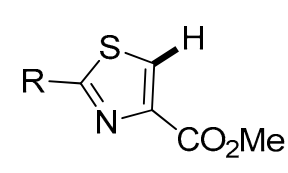

60

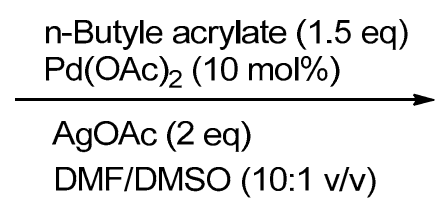

$115^{\circ} \mathrm{C}, 48 \mathrm{~h}$

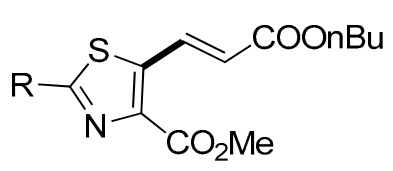

61

Scheme 18: Synthesis of Thiazole derivatives.

The coumarin ring system is an essential building block in a variety of natural products and biologically active compounds [21]. Because of their diverse physiological activities such as antibacterial, anticoagulant, antioxidant, and anti-inflammatory, these heterocycles have great importance in organic chemistry. The 4-arylcoumarin skeleton forms the major structural component of neoflavones, a type of neoflavonoids [22]. A number of methods are reported in the literature to access coumarin scaffolds. Among these, direct substitution at C-4 of the preformed coumarin ring is reported as an efficient strategy [23, 24]. Finet and co-workers have reported the synthesis of polyoxygenated 4-heteroaryl substituted coumarins by the Suzuki-Miyaura cross-coupling utilizing heteroaryl boronic acids and 4-trifluoromethylsulfonyloxycoumarins [25]. Very recently Duan et al. [26] reported Pd-catalyzed oxidative Heck coupling to access 4-arylcoumarins using coumarins and arylboronic acids. Glass and co-workers reported a fluorescent chemosensor for studying 
neurotransmitters for which a key synthetic step was a Suzuki coupling of phenylboronic acid to a chlorocoumarin.

Firstly cross-coupling of 4-chloro-3-(hydroxymethyl) coumarin $\mathbf{6 2}$ with potassium vinyltrifluoroborate was explored. Initial investigations for Suzuki reaction conditions were disappointing as no product formation was observed using $\mathrm{Pd}(\mathrm{OAc})_{2}$ as catalyst. $\mathrm{Pd}(\mathrm{dppf}) \mathrm{Cl}_{2}-\mathrm{CH}_{2} \mathrm{Cl}_{2}$ has been successfully employed as catalyst in many cross-coupling reactions involving potassium aryltrifluoroborates as coupling partners. Gratifyingly, 4-chlorocoumarin 62 underwent coupling with potassium vinyltrifluoroborate when $\mathrm{Pd}(\mathrm{dppf}) \mathrm{Cl}_{2}-\mathrm{CH}_{2} \mathrm{Cl}_{2}(10 \mathrm{~mol} \%)$ was used as catalyst (Scheme 19). Several combinations of base, solvent, and reaction time were explored. Consistent with the literature precedents, addition of water as co-solvent or use of a protic solvent was required for the cross-coupling as no conversion was observed when the reaction was attempted in dry toluene under reflux condition. Reducing the amount of base from 3 equiv to 1.5 equiv and halving the catalytic loading to $5 \mathrm{~mol} \%$ showed a slight improvement in yield (92\%) albeit with longer reaction time [27].<smiles>O=C1Oc2ccccc2C(Cl)C1CO</smiles>

62

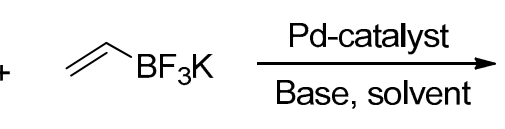

63<smiles>C=CC1c2ccccc2OC(=O)C1CO</smiles>

64

Scheme 19: Synthesis of Coumarin derivatives

A series of 5- and 8-methoxypsoralen (MOP) analogs, suitable for structure antioxidative/antiinflammatory activity relationship studies, were synthesized using as key-reactions the selective monobromination of MOPs with N-bromosaccharin and either a Heck reaction or a Suzuki coupling or a Suzuki coupling followed by a Wittig reaction to install side-chains of the acrylate- or benzoateor cinnamate-type, respectively. Analog65 was a more potent anti-inflammatory agent. Suzuki coupling between bromide 66 and 4-(4,4,5,5-tetramethyl-1,3,2-dioxaborolan-2-yl)benzaldehyde (TDBBAl) in the presence of $\mathrm{PdCl}_{2}(\mathrm{dppf})$ and $\mathrm{K}_{2} \mathrm{CO}_{3}$ in $\mathrm{THF}$ at $67^{\circ} \mathrm{C}$ for $4 \mathrm{~h}$ gave the anticipated aromatic aldehyde (67) in $80 \%$ yield (Scheme 20) [28].<smiles>COC(=O)/C=C/c1c2ccoc2c(OC)c2oc(=O)ccc12</smiles>

8-methoxypsoralen (MOP) analog<smiles>COc1c2occc2c(Br)c2ccc(=O)oc12</smiles>

66

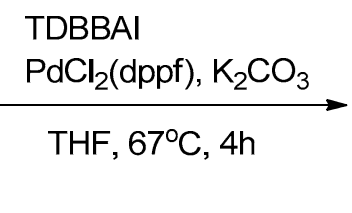

TDBBAI

THF, $67^{\circ} \mathrm{C}, 4 \mathrm{~h}$<smiles>COc1c2occc2c(-c2ccc(C=O)cc2)c2ccc(=O)oc12</smiles>

67

Scheme 20: Synthesis of Coumarin derivatives5- and 8-methoxypsoralen (MOP) analogs

Flavones (2-arylchromones) are very important oxygenated heterocyclic compounds. They belong to the flavonoid group, and occur naturally in fruits, vegetables, seeds, and flowers as 
secondary metabolites. They play important roles in plant development, reproduction, and defense and possess a wide range of biological and pharmaceutical activities. This includes antiviral, antiinflammatory, hepatoprotective, antioxidant, antithrombotic, vasodilating, and anticarcenogenic activity, combining high efficiency and low toxicity. The reaction of 68 with triflic anhydride $\left(\mathrm{Tf}_{2} \mathrm{O}\right.$; 2.4 equiv.) is reported in scheme resulted in the formation of the mono-triflate 69 in $80 \%$ yield. The expected bis-triflate was not formed. The yield of 69 slightly dropped when only 1.2 equiv. of triflic anhydride was employed. The synthesis of $\mathbf{6 9}$ and a Stille reaction of the latter has been previously reported. The Suzuki-Miyaura reaction of mono-triflate $\mathbf{6 9}$ with various arylboronic acids, afforded the 7-aryl-5-hydroxyflavones 70 in 75-90\% yields (Scheme 21). The reactions were carried out under standard conditions [3 mol- $\%$ of $\left[\mathrm{Pd}\left(\mathrm{PPh}_{3}\right)_{4}\right]$ as the catalyst, $\mathrm{K}_{3} \mathrm{PO}_{4}$ as the base, 1,4-dioxane, $\left.80{ }^{\circ} \mathrm{C}\right]$. Very good yields were obtained both for electron-rich and -poor arylboronic acids. The yields for arylboronic acids containing an ortho substituent were slightly lower than those of other arylboronic acids, presumably due to steric effects [29].<smiles>O=c1cc(-c2ccccc2)oc2cc(O)cc(O)c12</smiles>

68

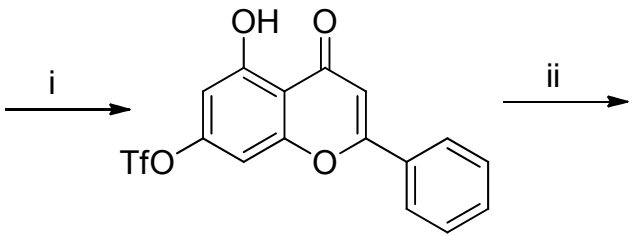

69<smiles>O=c1cc(-c2ccccc2)oc2cc(Br)cc(O)c12</smiles>

70

i) 1 (1.0 eq), pyridine (4.0 eq), $\mathrm{CH}_{2} \mathrm{Cl}_{2}, \mathrm{Tf}_{2} \mathrm{O}(2.4 \mathrm{eq}) 20^{\circ} \mathrm{C}, 4 \mathrm{~h}$

ii) 2 (1.0 eq), $\mathrm{ArB}(\mathrm{OH})_{2}(1.0 \mathrm{eq}), \mathrm{K}_{3} \mathrm{PO}_{4}$ (1.5 eq), $\left[\mathrm{Pd}\left(\mathrm{PPh}_{3}\right)_{4}\right](3 \mathrm{~mol} \%), 1,4$-dioxane, $80^{\circ} \mathrm{C}, 4 \mathrm{~h}$

Scheme 21: Synthesis of Flavone (2-arylchromones) Derivatives.

Within the azole series, imidazole is the most prominent ring system. It plays a significant role in many compounds with biological activity or in natural products. Therefore, the most crosscoupling literature is available, and many different methods have successfully been applied. SuzukiMiyaura cross-coupling of highly functionalized 4-iodoimidazole $\mathbf{7 2}$ with pyrimidineboronic acid $\mathbf{7 3}$ to give $\mathbf{7 4}$ has been reportedin $67 \%$ yield (Scheme 22). Other examples for the use of substituted 4iodoimidazoles can be found in the literature. Additionally, 5-iodoimidazoles were also successfully cross-coupled under Suzuki-Miyaura conditions, by using phenylboronic acids as coupling partners, in good yields (68-79\%) [30].

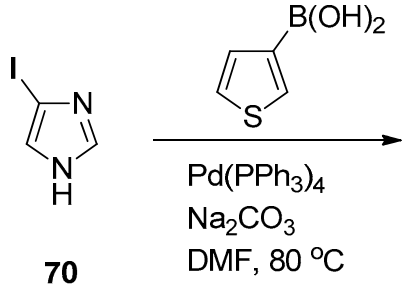

70

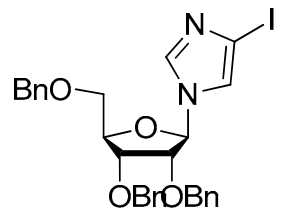

72

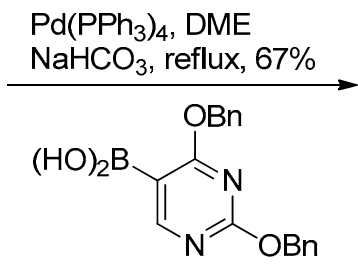

73<smiles>CC(C)(C)c1ccsc1</smiles>

71<smiles>Oc1ncc(-c2cn(C3OC(COc4ccccc4)C(OCc4ccccc4)O3)cn2)c(Br)n1</smiles>

74

Scheme 22: Suzuki-Miyaura cross-coupling of highly functionalized 4-iodoimidazole. 
In addition to iodides, bromides can serve as leaving groups. A double cross-coupling reaction in the 4-position was accomplished on biimidazole 75 to give 76 in $55 \%$ yield (Scheme 23) [31].<smiles></smiles>

75

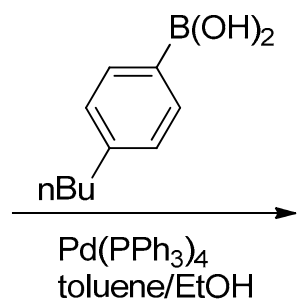

toluene/EtOH<smiles>[R14]Sn1c(-c2nc(-c3ccc(CCC)cc3)c(C=O)n2[R15]#[M])nc(-c2ccc(CCCC)cc2)c1C=O</smiles>

76

Scheme 23: Double cross-coupling reaction on biimidazole.

2-Benzazepine is not only a unique aromatic fused aza-heterocyclic structure but also a core component of a number of pharmacologically important compounds. Benzazepine derivatives exhibit a variety of biological activities such asanalgesic, antiarrhythmic, anticonvulsant, and hypertensive activities. 2-(2-bromophenyl)-2,3,4,5-tetrahydro-1H-benzo[c]azepine (77) was picked for structural elaboration through various palladium-mediated coupling reactions for molecular assortment (Scheme 24). Accordingly, bromo derivative77was subjected to Suzuki coupling reaction. The Suzuki reaction was carried out by using $6 \mathrm{i}$ (1.0 equiv), a boronic acid (1.15 equiv.), $\mathrm{Pd}\left(\mathrm{PPh}_{3}\right)_{4}$ (5 $\mathrm{mol} \%$ ), and $\mathrm{K}_{3} \mathrm{PO}_{4}$ (2 equiv) in dimethoxy ethane at $90^{\circ} \mathrm{C}$ [32].<smiles>Brc1ccccc1N1CCCc2ccccc2C1</smiles>

77

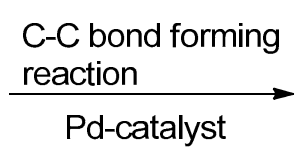

$\mathrm{W}=$ aryl or alkenyl<smiles>N#[W]c1ccccc1N1CCCc2ccccc2C1</smiles>

78

Scheme 24 Voltage-gated ion channels $(\mathrm{Na}+, \mathrm{K}+\mathrm{Ca} 2+)$ play a critical role in neuroexcitability especially at synapses through the release of neurotransmitters Voltage gated sodium channels (VGSCs), and particularly subtype hNav1.7, have recently emerged as a target of interest as they can contribute to nociception. Moreover, clinical genetics studies have shown that hNav1.7 is strongly connected to the transduction of pain signals. Thus, a great deal of work has been devoted to the discovery of hNav1.7 antagonists, and this has culminated with the synthesis of XEN 90779 and other tetracyclic spirooxindole blockers such as 80 [33].<smiles>CCCCCN1C(=O)C2(COc3cc4c(cc32)OCO4)c2ccccc21</smiles>

79 XEN 907<smiles>COc1ccc2c(c1)C1(CO2)C(=O)N(Cc2ccc(C(F)(F)F)o2)c2ccccc21</smiles>

80 spiriixindole blocker

Because of presence of spirooxindoles in many biologically active compounds and pharmaceuticals, it urged the organic chemists to develop new methods for their synthesis. However, a new method for the synthesis of tetracyclic spirooxindoles fused with a five-, six-, or seven- 
membered heterocyclic condensed with a pyridine core has been reported in a recent paper [34]. Three series of new spirooxindole derivatives were efficiently synthesized containing a five-, six-, or seven-membered heterocyclic with an amine, ether, or amide functionality.

1-pentyl-2H-spiro[furo[2,3- $b$ ]pyridine-3,3_-indoline]-2-one (81) was successfully obtained in good yield from 3-(2-oxo-1H-pyridin-3-yl)-1-pentylindolin-2-one and diiodomethane. As SuzukiMiyaura cross-coupling reactions require aryl halides for coupling, we initially focused on the bromination of the aromatic counterparts. Thus, treatment of compound 81 with $\mathrm{N}$ bromosuccinimide(1.2 equiv.) in refluxing methanol for $1 \mathrm{~h}$ gave monobromo-spirooxindole 82 in an excellent yield of $98 \%$ (Scheme 25 ).<smiles>O=C1N(P)c2ccccc2C12COc1ncccc12</smiles>

81

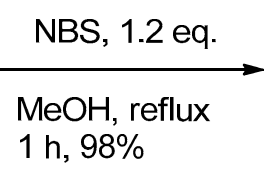

$1 \mathrm{~h}, 98 \%$<smiles>O=C1N(P)c2ccc(Br)cc2C12COc1ncccc12</smiles>

82

Scheme 25: Bromination of the aromatic counterparts.

The reactivity of compound $\mathbf{8 2}$ in Suzuki-Miyaura cross coupling reactions was then examined. All reactions required (hetero)arylboronic acid (1.2 equiv.), $\mathrm{Pd}\left(\mathrm{PPh}_{3}\right)_{4} \quad$ (0.05 equiv.), and $\mathrm{K}_{2} \mathrm{CO}_{3}(2.0$ equiv.), and were carried out in a 2:1 mixture of toluene and ethanol at $150^{\circ} \mathrm{C}$ under microwave irradiation for $10 \mathrm{~min}$. Monosubstituted 5-(het)aryl-1-pentyl-2H-spiro[furo-[2,3-b]pyridine-3,3indolin]-2-one 84 was obtained in good to excellent yields (75-97\%) after purification by column chromatography (Scheme 26).<smiles>O=C1N(P)c2ccc(Br)cc2C12COc1ncccc12</smiles>

83

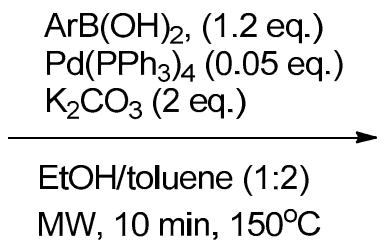<smiles>O=C1N(P)c2ccc(Br)cc2C12COc1ncccc12</smiles>

84

Scheme 26: SM cross coupling of Brominated Product.

Imidazo[1,2-a]pyridines have recently been attracting considerable attention because they represent promising building blocks with potential pharmaceutical applications. Substituted imidazo[1,2-a]pyridine compounds have revealed magical biological activities like melatonin receptor ligands and antiviral, antiulcer, antibacterial and antifungal agents. They have also been reported as benzodiazepine receptor agonists, calcium channel blockers, $\beta$-amyloid formation inhibitors, ligands for detecting $\beta$-amyloid, herbicides, cyclin-dependent kinase (CDK) inhibitors, and GABAA receptor modulators. Imidazo[1,2-a]pyridines are designated as a new class of orally active nonpeptide bradykinin $\beta 2$ receptor antagonists and as inhibitors of cyclooxygenase-2 (COX-2) with a high selectivity in relation to COX-1. In literature, they have also been reported as anticancer, analgesic, antipyretic, and anti-inflammatory agents, for the therapeutic treatment of diabetes, as active agents for treating or preventing schizophrenia, Alzheimer's disease, dementia, and depression, as antihypertensive agents, as cholesterol acyltransferase (ACAT) inhibitors, as potential antiprotozoal agents, and as geranylgeranyl transferase inhibitors (RGGT). Recently, they have been found to show potent anticonvulsant activity. Additionally, the imidazo[1,2-a] pyridine system is also present in pharmacologically important drugs, including several anxyolytics, such as Alpidem, 
Necopidem, Saripidem, and Zolpidem. Moreover, the imidazo[1,2-a]pyridine derivative Olprinone is available as an inhibitor of PDE 3/436, whereas Zolimidine has a gastroprotective effect and is used to treat peptic ulcers. Recently, several other experimental molecules have been reported as promising drugs [35].

Gueiffier and co-workers reported Suzuki-Miyaura cross-coupling at the 3-position of imidazo[1,2-a]pyridines 85 [36]. They concluded that the cross-coupling was more efficient with use of $\mathrm{Pd}\left(\mathrm{PPh}_{3}\right)_{4}$, inorganic bases $\left[\mathrm{Na}_{2} \mathrm{CO}_{3}, \mathrm{Ba}(\mathrm{OH})_{2}\right.$, or $\left.\mathrm{NaOH}\right]$, and DME or THF as solvent (Scheme 27).

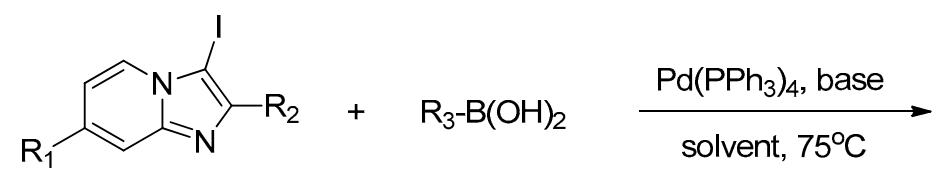

85
86<smiles>[R]c1ccn2c([R])c([R])nc2c1</smiles>

87
Bases: $\mathrm{Na}_{2} \mathrm{CO}_{3}, \mathrm{NaOH}, \mathrm{Ba}(\mathrm{OH})_{2}$ Solvent: DME or THF

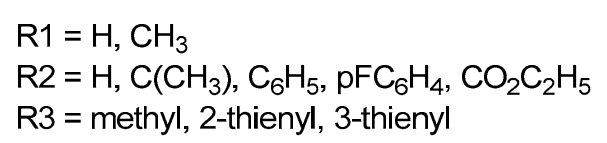

Scheme 27: Suzuki-Miyaura cross-coupling reactions of 85.

Moreover, Warshakoon et al. reported the preparation of a new series of imidazo[1,2-a]pyridine derivatives by means of Suzuki-Miyaura cross coupling [37]. They demonstrated that the nature of boronic acid played significant role on the reactivity (reaction times and yields) as well as by the substituent at the 2-position, yields of isolated products 89 ranged from 47 to $91 \%$.

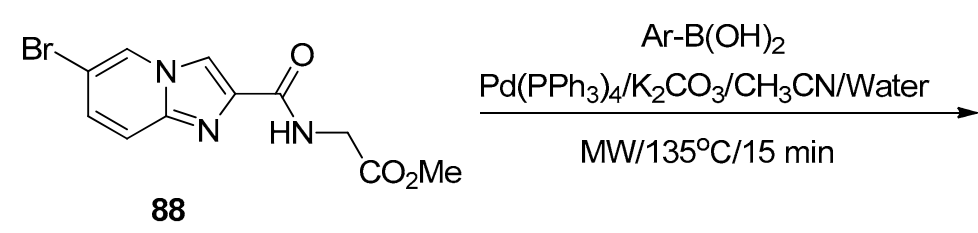

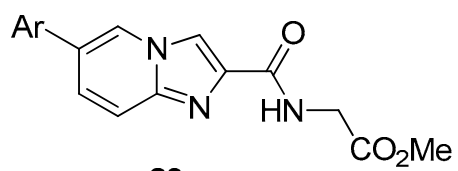

89

Scheme 28: Synthesis of compounds 89 by Suzuki-Miyaura cross-coupling.

Interestingly, 7-methyl-3-[3-(pyridin-3-yl)phenyl]imidazo- [1,2-a]pyridine (94) was identified as a new GABAA ligand with some structural similarity to the high-efficacy GABAAR3 agonist NS2710. Compound 94 showed a binding affinity for the GABAAR3 subtype similar to that of diazepam but is essentially a benzodiazepine (BZ) antagonist. 3-Bromo-7-methylimidazopyridine (90) was first treated with (3-methoxyphenyl)boronic acid following the Suzuki-Miyaura cross-coupling conditions, which led to the formation of intermediate 92 in $93 \%$ yield. Compound 92 was converted into boronate ester 93 in further three steps. Then, access to 94 by Suzuki cross-coupling of the boronate ester 93 with 3-bromopyridine was achieved with an aprotic solvent such as DME in the presence of $\mathrm{Pd}(\mathrm{PPh} 3) 4$ as catalyst (Scheme 29) [38]. Compound 94 was prepared in five steps starting from 90 . 
<smiles>COc1cccc([Hg]O[Na])c1</smiles>

(a) $\mathrm{HBr}, \mathrm{AcOH}$, reflux, 95\%

(b) $\mathrm{Tf}_{2} \mathrm{O}$, pyridine, $\mathrm{DCM}, 0^{\circ} \mathrm{C}$ to r.t, $60 \%$

(c) bis(pinacolato)diboron, $\mathrm{PdCl}_{2}$ (dppf), dppf, KOAc, 1,4-dioxane, $80^{\circ} \mathrm{C}, 90 \%$<smiles>Cc1ccn2c(-c3cccc(-c4cccnc4)c3)cnc2c1</smiles>

94

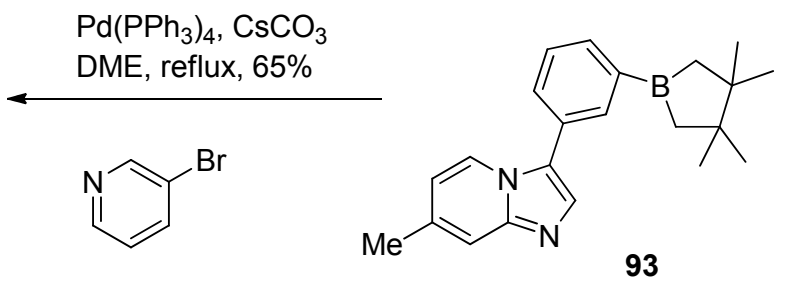

Scheme 29: Synthesis of 35 through two successive Suzuki-Miyaura reactions.

The $4 H$-pyrido[1,2-a]pyrimidin-4-one core has proved to be a successful and significant scaffold for the development of biologically interesting molecules, and their pharmacological activity has been extensively reported in various biological areas. These interesting biological properties provoke the scientist to accept such important challenges for their synthesis. Reactivity of this heterocycle in the Suzuki cross-coupling reaction is reported in literature on the basis of the previous studies on the use of microwave heating. However, the design and synthesis of these charming biological compounds have been done by adopting the Suzuki-Miyaura coupling reaction. Using microwave heating with the 7-chloro-3-iodo-4H-pyrido[1,2-a]-pyrimidin-4-one derivative along with experimental Suzuki- Miyaura led to the monoarylated compound in the 3-position (Scheme 30).<smiles>CC(=O)OCc1nc2ccc(Cl)cn2c(=O)c1I</smiles>

95

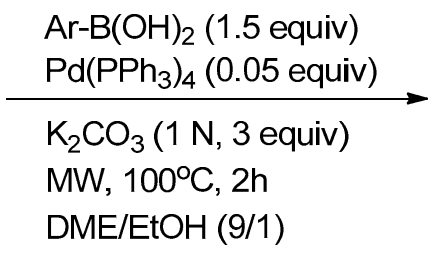<smiles>CC(=O)OCc1nc2ccc(Cl)cn2c(=O)c1Br</smiles>

96

Scheme 30: Suzuki-Miyaura cross-coupling reaction.

The required starting material, compound 101, for the Suzuki- Miyaura bis(cross-coupling) study (scheme 31) was synthesized from 5-chloropyridin-2-amine in four steps by the chlorination of 5-chloropyridin-2-amine with $\mathrm{N}$-chlorosuccinimide. (NCS) in refluxing $\mathrm{MeCN}$ (acetonitrile), followed by a condensation reaction with ethyl 4-chloroacetoacetate in polyphosphoric acid (PPA) using the Ferrarini procedure, which produced 7,9-dichloro-2-(chloromethyl)-4H-pyrido[ 1,2a]pyrimidin-4-one (99). Iodination of compound 99 with $\mathrm{N}$-iodosuccinimide (NIS) in refluxing $\mathrm{MeCN}$ and subsequent acetylation using potassium acetate in dimethylformamide (DMF) provided (7,9dichloro-3-iodo-4-oxo- 4H-pyrido[1,2-a]pyrimidin-2-yl)methyl acetate (101) as described in Scheme 27 [39]. 
16 of 31<smiles>Nc1ccc(Cl)cn1</smiles>

97

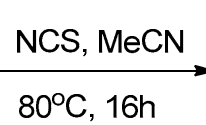

$80^{\circ} \mathrm{C}, 16 \mathrm{~h}$<smiles>Nc1ncc(Cl)cc1Cl</smiles>

98<smiles>CCOC(=O)CC(=O)CCl</smiles>

$110^{\circ} \mathrm{C}, 3 \mathrm{~h}$<smiles>O=c1c(I)c(CCl)nc2c(Cl)cc(Cl)cn12</smiles><smiles>CC(=O)OCc1nc2c(Cl)cc(Cl)cn2c(=O)c1I</smiles><smiles>CCOC(C)=O</smiles>

101<smiles>O=c1c(I)c(CCl)nc2c(Cl)cc(Cl)cn12</smiles>

Scheme 31: Synthesis of the starting material 101.<smiles>CC(=O)OCc1nc2c(Cl)cc(Cl)cn2c(=O)c1I</smiles>

101

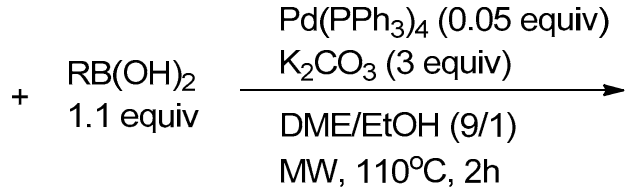

$\mathrm{MW}, 110^{\circ} \mathrm{C}, 2 \mathrm{~h}$<smiles>CC(=O)OCc1nc2c(Cl)cc(Cl)cn2c(=O)c1Br</smiles>

102

Scheme 32: Suzuki-Miyaura monocoupling reaction of 101 with boronic acid.

Exploratory experiments were started with the coupling of benzenesulfonyl chloride and 4methoxyphenylboronic acid under different conditions such as various nickel catalysts, bases, and solvents. Much effort was devoted to this task, but low yields (20\%) of the biaryl product were obtained. The starting sulfonyl chloride was totally consumed in all cases, which could be explained by the fact that the sulfonyl chloride was converted into the corresponding sulfonate in boiling solvents in the presence of base. However, the yield could be increased drastically under the same conditions if $\mathrm{N}, \mathrm{N}$-diphenylsulfonylmethylamine $\left[\mathrm{CH}_{3} \mathrm{~N}\left(\mathrm{SO}_{2} \mathrm{Ar}\right)_{2}\right]$ was used instead of benzenesulfonyl chloride. A systematic study was conducted to optimize the critical reaction conditions [40].<smiles>CN(OS(=O)(=O)c1ccccc1)c1ccccc1</smiles>

106<smiles>O</smiles><smiles>[B]1CCCCC1</smiles>

107

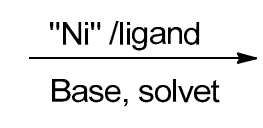

07

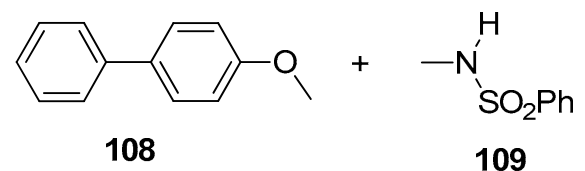

109

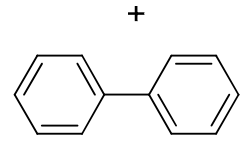

110

Scheme 33: Suzuki coupling reaction using $\mathrm{Ni}$ as catalyst.

On the basis of wide range of attractive biological properties and their ease of adjustment in every situation, it has urged chemists to study the diverse structure of triazine. Therefore, a huge number of synthetic approaches are reported by scientific groups and others have transformed the triazine structure into an important scaffold in drug discovery programs. Cyanuric chloride are efficiently used along with amine, thiol, and alcohol building blocks for the formation of 1,3,5- 
Triazine derivatives that involve the formation of C-heteroatom bonds. In contrast, the derivatization of the triazine scaffold forming $\mathrm{C}-\mathrm{C}$ bonds has been much lesser explored. For instance, although aryl-aryl motifs are well-known pharmacophores and widely employed in the derivatization of privileged scaffolds, only few examples show the synthesis of diaryl or aryl and alkyl-substituted triazines. Moreover, recently reported efficient synthetic schemes for triazine libraries with single $\mathrm{C}-\mathrm{C}$ bonds using either Grignard reactions or Suzuki couplings are reported. Herein, the solid-phase synthesis of 4,6-diaryl and 4-aryl, 6-alkyl 1,3,5-triazines by combining Grignard reactions and Suzuki couplings and their evaluation for efficient biofuel generation, which yielded to the discovery of E4 as a unique chemical regulator of the biolipid production is reported. The orthogonal synthesis of a two-dimensional library by combining a solution phase Grignard reaction followed by a solid-phase Suzuki coupling was is explained. Cyanuric chloride was initially derivatized by 12 different Grignard reagents under reported conditions including alkyl and aryl groups on the 6-position of the triazine scaffold. The resulting 2,4-dichloro-6-alkyl-1,3,5-triazines were loaded onto an amine derivatized PAL-polystyrene (PAL-PS) resin to accelerate their further combinatorial derivatization. PAL-PS resins are compatible with palladium-catalyzed cross-coupling conditions, and have been used for the preparation of tagged triazine libraries (Scheme 34) [41].

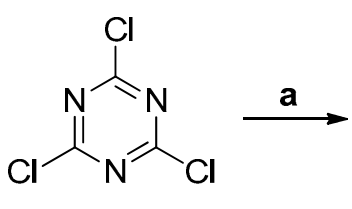

111<smiles>[R]c1nc(Cl)nc(Cl)n1</smiles><smiles>[R]c1nc(Cl)nc(N(CO)CCOCCOCCNC(=O)OCc2ccccc2)n1</smiles>

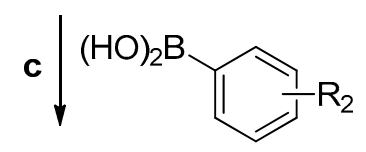<smiles>[R]c1ccc(-c2nc([R])nc(NCCOCCOCCN)n2)cc1</smiles>

115

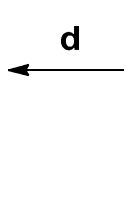

114

Reagents and conditions: (a) R1-MgX, THF, $0{ }^{\circ} \mathrm{C}$ to r.t., $8 \mathrm{~h}$; (b)PAL-PS amine-derivatized resin, THF, DIEA, $60{ }^{\circ} \mathrm{C}, 3 \mathrm{~h}$; (c) $\mathrm{Pd}\left(\mathrm{PPh}_{3}\right)_{4}$, dioxane, $\mathrm{R} 2-\mathrm{B}(\mathrm{OH})_{2}, \mathrm{Cs}_{2} \mathrm{CO}_{3}, 90^{\circ} \mathrm{C}, 215$ h; (d) TFADCM (1:9), r.t., 0.5 h.

Scheme 34: Synthesis of 4,6-Diaryl and 4-Aryl, 6-Alkyl-1,3,5-triazine Compounds.

Despite progress made in recent years in discovering new compounds with antiangiogenic activity, the researchers are still conscious to develop new methodologies for the better treatment of diseases characterized by abnormal angiogenesis including tumors. Tubulin has been identified as the possible molecular target for chemotherapeutic agent in cancer treatment in new fields of research. Polymeric microtubules contain tubulin as a dynamic constituent. Microtubules are the major component of mitotic spindles and they play significant role in cell division and cell structure. Microtubules are an attractive pharmacological target for anticancer drug discovery and the substances used for their polymerization or depolymerization are under great consideration as they 
have attractive properties in biological fields. A new series of compounds in which the 2-amino-5chlorophenyl ring of phenstatin analogue was replaced with a 2-amino-5-aryl thiophene was synthesized and evaluated for antiproliferative activity and for inhibition of tubulin polymerization and colchicine binding to tubulin.2-Amino-3-(3,4,5-trimethoxybenzoyl)thiophene derivatives with general structure 117 was synthesized as shown in the reaction sequence reported in Scheme 31. 2Amino-3-aroyl thiophenes $\mathbf{1 1 7}$ was obtained by a one-step procedure applied to $\alpha$-ketonitriles $\mathbf{1 1 6}$ and the appropriate aldehyde or ketone with sulfur and triethylamine (TEA) as base in refluxing ethanol. Compound $\mathbf{1 1 7}$ was synthesized by a two-step procedure consisting of a Knoevenagel reaction of $\mathbf{1 1 6}$ and acetophenone in benzene in the presence of $\hat{a}$-alanine and acetic acid, followed after isolation and purification of the $E$ - and Z-olefin isomers, by a cyclization in ethanol with sulfur in the presence of TEA. The 5-unsubstituted thiophene derivative $\mathbf{1 1 7}$ was transformed almost quantitatively into the corresponding $N$-phthalimido derivative 118 using phthalic anhydride in refluxing acetic acid. The subsequent regioselective bromination of $\mathbf{1 1 8}$ in a mixture of acetic acid and sodium acetate, using a calculated amount of bromine, produced intermediate 5-bromothiophene derivative $\mathbf{1 1 9}$ in good yields. The formation of the 4-bromothiophene isomer of compound $\mathbf{1 1 8}$ was not observed. The preparation of the thiophene 5-iodo substitution 119 was carried out by stirring 118 in acetic acid with $\mathrm{N}$-iodosuccinimide (NIS) at $50{ }^{\circ} \mathrm{C}$. 5-aryl thiophene compound120 was synthesized from key intermediate $\mathbf{1 1 9}$ by a standard Suzuki cross-coupling reaction with appropriate aryl boronic acids under heterogeneous conditions $\left(\mathrm{Pd}\left(\mathrm{PPh}_{3}\right)_{4}, \mathrm{~K}_{2} \mathrm{CO}_{3}\right)$ in refluxing toluene [42].

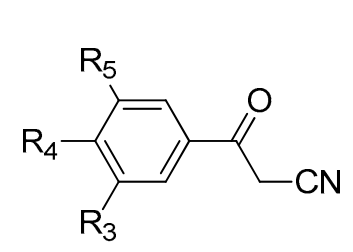

116

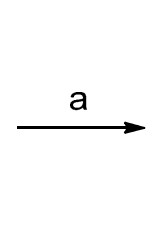<smiles>[R]c1cc(C(=O)c2c(N)sc([R])c2[R])cc([R5])c1[R]</smiles>

117
(1)
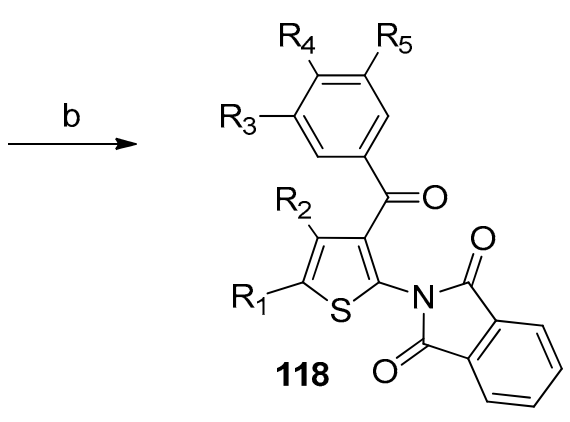

C

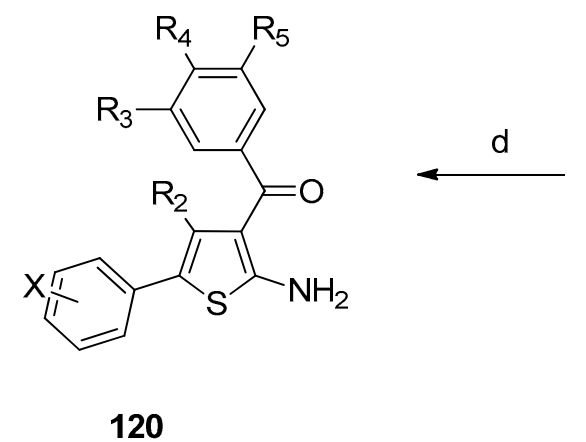

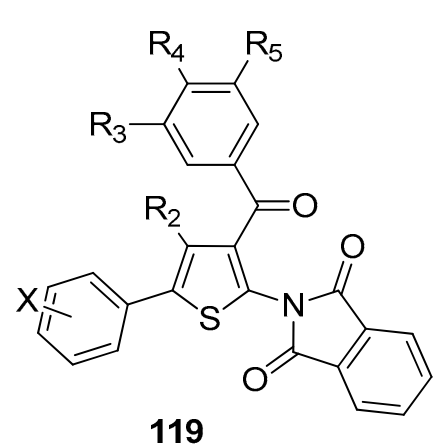

Scheme 35: Synthesis of 2-Amino-3-(3,4,5-trimethoxybenzoyl)thiophene derivatives.

Reagents: a: ketone or aldehyde, S8, TEA, $\mathrm{EtOH}, 70{ }^{\circ} \mathrm{C}$ for $2 \mathrm{~h}$; b: phthalic anhydride, $\mathrm{AcOH}$; c: $\operatorname{ArB}(\mathrm{OH})_{2}, \mathrm{Pd}\left(\mathrm{PPh}_{3}\right)_{4}, \mathrm{Na}_{2} \mathrm{CO}_{3}, \mathrm{PhMe}, \mathrm{rx}, 18$ h; $\mathbf{d}: \mathrm{NH}_{2} \mathrm{NH}_{2}, \mathrm{EtOH}$.

Flurbiprofen, a nonsteroidal anti-inflammatory drug (NSAID), has been recently described to selectively inhibit $\beta$-amyloid (A $\beta 42)$ secretion. More recently, it has been shown that some NSAIDs decrease the production of Aâ42 in vitro and in vivo [43-45]. New flurbiprofen analogues were synthesized, with the target of increasing A $\beta 42$ inhibitory potency while removing anti-COX activity. 
In vitro ADME developability parameters were taken into account in order to identify optimized compounds at an early stage of the project. Appropriate substitution patterns at the alpha position of flurbiprofen allowed for the complete removal of anti-COX activity, while modifications at the terminal phenyl ring resulted in increased inhibitory potency on A $\beta 42$ secretion. In rats, some of the compounds appeared to be well absorbed after oral administration and to penetrate into the central nervous system. Studies in a transgenic mice model of AD showed that selected compounds significantly decreased plasma Aâ42 concentrations. These new flurbiprofen analogues represent potential drug candidates to be developed for the treatment of AD.Several possible chemical variations were considered and implemented on the basis of flurbiprofen structure (Fig. 1) [46].

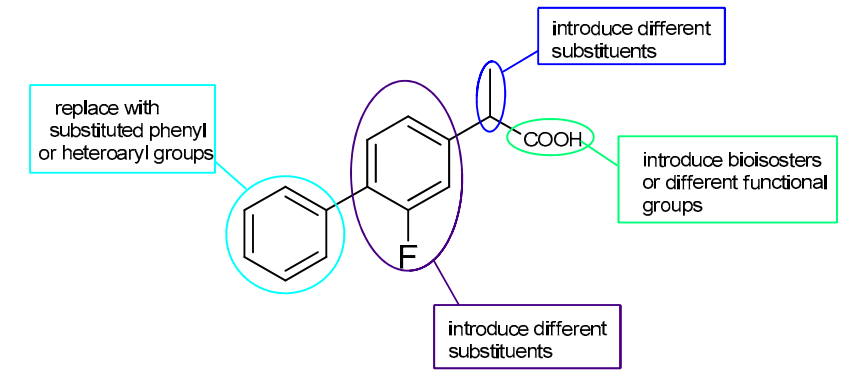

Fig. 1: Planned Chemical Variations on Flurbiprofen

A first array of compounds was synthesized through a Suzuki coupling reaction between 124 and the suitable commercially available aryl or heteroaryl boronic acids. The anion of diethyl 2methylmalonate was reacted with 2,4-difluoronitrobenzene to obtain 121. After catalytic hydrogenation, the resulting amine $\mathbf{1 2 2}$ was converted into the corresponding diazonium salt that was reacted with potassium iodide to obtain 123. Finally, hydrolysis and decarboxylation of $\mathbf{1 2 3}$ afforded 124 in $57 \%$ overall yield. Suzuki couplings were performed on $1 \mathrm{mmol}$ scale in a parallel way by employing a Myriad Personal Synthesizer. Intermediate 124 was reacted with the appropriate boronic acids in 1,2-dimethoxyethane at $80{ }^{\circ} \mathrm{C}$ in the presence of tetrakis(triphenylphosphine)palladium and aqueous sodium carbonate to obtain 125a-o (Table 1). 
Table 1. Variations of the Aromatic Rings of Flurbiprofen.

\begin{tabular}{|c|c|c|c|c|}
\hline Compound & R1 & $\mathrm{R} 2$ & $\begin{array}{c}\text { A } \beta 42 \text { inhibition } \\
\quad(@ 100 \text { íM) }\end{array}$ & $\begin{array}{l}\text { IC50 } \\
(\mathrm{i} M)^{\mathrm{a}}\end{array}$ \\
\hline flurbiprofen & phenyl & $3-F$ & $30 \%$ & 305 \\
\hline $125 a$ & 3,4-dichlorophenyl & $3-F$ & $87 \%$ & 75 \\
\hline $125 b$ & 3,5-dichlorophenyl & $3-F$ & $75 \%$ & 77 \\
\hline $125 \mathrm{c}$ & 2-chlorophenyl & $3-F$ & $13 \%$ & nda $^{a}$ \\
\hline $125 d$ & 3-chlorophenyl & $3-\mathrm{F}$ & $58 \%$ & nd \\
\hline $125 e$ & 4-chlorophenyl & $3-\mathrm{F}$ & $55 \%$ & nd \\
\hline $125 \mathrm{f}$ & 4-cyclohexylphenyl & $3-F$ & $79 \%$ & 21 \\
\hline $125 \mathrm{~g}$ & 4-methylphenyl & $3-F$ & $44 \%$ & nd \\
\hline $125 \mathrm{~h}$ & 4-CF3 phenyl & $3-F$ & $60 \%$ & 129 \\
\hline $125 \mathrm{i}$ & 2-CF3 phenyl & $3-\mathrm{F}$ & $25 \%$ & nd \\
\hline $125 j$ & 3-benzothienyl & $3-F$ & $96 \%$ & 83 \\
\hline $125 k$ & 3-thienyl & $3-F$ & $40 \%$ & nd \\
\hline 1251 & 4-pyridyl & $3-F$ & $11 \%$ & nd \\
\hline $125 \mathrm{~m}$ & 4-methoxyphenyl & $3-\mathrm{F}$ & $67 \%$ & 67 \\
\hline $125 n$ & 3,4 methylendioxyphenyl & $3-F$ & $42 \%$ & 210 \\
\hline 1250 & 4-hydroxyphenyl & $3-\mathrm{F}$ & $27 \%$ & nd \\
\hline
\end{tabular}

${ }^{a}$ nd $=$ not determined.<smiles>CCOCC(C)(C(=O)OCC)C(C)(C)C</smiles><smiles>[R]c1ccc(C(C)C(=O)O)cc1F</smiles>

125

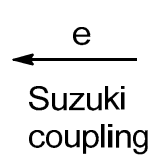<smiles>CC(C(=O)O)c1ccc(I)c(F)c1</smiles>

124<smiles>CCOCC(C)(C(=O)OCC)c1ccc(I)c(F)c1</smiles>

123

\section{Scheme 36}

Reagents and conditions: (a) NaH, DMSO; (b) $\mathrm{H}_{2}, \mathrm{Pd} / \mathrm{C}$; (c) $1 . \mathrm{NaNO}_{2}, \mathrm{HCl}, 0^{\circ} \mathrm{C}$; 2. $\mathrm{KI}$; (d) $\mathrm{NaOH}$, $\mathrm{EtOH}-\mathrm{H}_{2} \mathrm{O}, 100{ }^{\circ} \mathrm{C}, 57 \%$ (four steps); (e) $\mathrm{R}^{1} \mathrm{~B}(\mathrm{OH})_{2}, \mathrm{Pd}\left(\mathrm{PPh}_{3}\right) 4, \mathrm{Na}_{2} \mathrm{CO}_{3}, \mathrm{DME}-\mathrm{H} 2 \mathrm{O}, 80^{\circ} \mathrm{C}$. 
After synthesizing the first array of biphenyl derivatives, a new synthetic pathway was developed in order to allow the synthesis of gem-disubstituted derivatives (Scheme 37). 4-Bromo-3fluorotoluene was brominated with NBS to afford 126 that reacted with potassium cyanide to obtain 127. From this intermediate gem-disubstituted derivatives $\mathbf{1 2 8}$ could be prepared by reaction with the appropriate methyl iodide or 1,2-dibromoethane. The cyano group was then hydrolyzed to obtain 129 that was submitted to a modified Suzuki coupling reaction to afford the expected biaryl compounds 130. The coupling was performed in ligand-free conditions [47] by reacting 130 with the suitable boronic acids in aqueous sodium carbonate in the presence of TBAB and $\mathrm{Pd}(\mathrm{OAc}) 2$. Reactions were performed at $120^{\circ} \mathrm{C}$ under microwave or conventional thermal heating in a sealed tube. These conditions gave a faster reaction time, improved yields and simplified the purification of crude materials.<smiles>[R4]C([R4])(C#N)c1ccc(Br)c(F)c1</smiles>

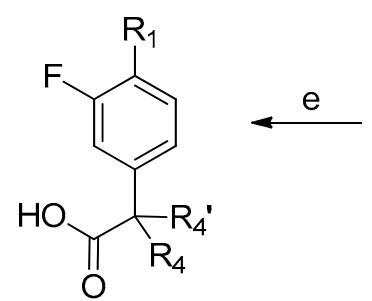

130<smiles>[R4]C([R4])(C(=O)O)c1ccc(Br)c(F)c1</smiles>

129

Scheme 37. Reagents and conditions: (a) NBS, CCl 4 ; (b) $\mathrm{KCN}, \mathrm{EtOH}$; (c) $\mathrm{RX}$ or $\mathrm{Br}\left(\mathrm{CH}_{2}\right)_{2} \mathrm{Br}, \mathrm{NaOH}$, toluene- $\mathrm{H}_{2} \mathrm{O}$; (d) $\mathrm{NaOH}, \mathrm{EtOH}-\mathrm{H}_{2} \mathrm{O}, 100{ }^{\circ} \mathrm{C}$; (e) $\mathrm{R} 1 \mathrm{~B}(\mathrm{OH})_{2}, \mathrm{Pd}(\mathrm{OAc}) 2, \mathrm{Na}_{2} \mathrm{CO}_{3}, \mathrm{TBAB}, \mathrm{H}_{2} \mathrm{O}, 120{ }^{\circ} \mathrm{C}$ (MW or oil bath, sealed tube).

In past eight years, there are found many forceful evidences that support the fact that c-jun-Nterminal kinase (JNK) serve as a good therapeutic target for the treatment of neurodegenerative disease. From a chemistry perspective, several JNK selective inhibitors have started to emerge and include compounds from classes such as indazoles, aminopyrazoles, aminopyridines, pyridine carboxamides, benzothien-2-ylamides and benzothiazol-2-yl acetonitriles, [48] quinoline derivatives, and aminopyrimidines. Synthesis of final compound is described in Scheme 38. Suzuki coupling of 2,4-dichloropyrimidine with synthesized boronate esters or commercially available boronic acids proceeded uneventfully to provide biaryl intermediates 133. In many instances, the crude products after aqueous workup were purified enough to react in final step in the synthesis; however, analytical samples were purified by silica gel chromatography to obtain the appropriate spectral data. Coupling of the 2-chloropyrimidine products with 4-substituted anilines proceeded under two different reaction conditions. The reactants could either be heated in aqueous ethoxyethanol at $120^{\circ} \mathrm{C}$ overnight or in anhydrous ethoxyethanol at $190^{\circ} \mathrm{C}$ for 1 hour. Products were typically precipitated out of the reaction mixture by addition of excess water and were sufficiently pure for in vitro testing or could be purified by silica gel chromatography or reversephase preparative HPLC [49]. 
<smiles>[R]c1ccc(Nc2nccc(-c3cc([R])c([R])c([R])c3)n2)cc1</smiles>

Scheme 38.Reagents and conditions: (a) $\mathrm{Pd}\left(\mathrm{PPh}_{3}\right)_{4}, 2 \mathrm{M} \mathrm{K}_{2} \mathrm{CO} 3$ and $\mathrm{DME}, 90^{\circ} \mathrm{C}, 10 \mathrm{~h}$, (OR = pinacol or $\mathrm{OH}$ ); (b) 4-substituted aniline and 2-ethoxyethanol, $120^{\circ} \mathrm{C}, 10 \mathrm{~h}$.

Arylquinolines are pharmaceutically important scaffolds as they find its vast applications in many molecules. In addition, they have also been designed and synthesized as key structural elements in materials science. Due to their structural rigidity with the nitrogen donor atom of quinolines, Song's group has recently developed a novel ligand incorporating 8-arylquinolines for activation of a $\mathrm{C}-\mathrm{Cl}$ bond of $\mathrm{CHCl}_{3}$ in the presence of Pt. Over the past four decades, transition-metal-catalyzed coupling reactions have evolved into an indispensable tool in academia and industry. Among the many known reactions, Suzuki-Miyaura couplings are particularly popular because of their significant benefits including reaction efficiency, mild conditions, high functional group tolerance, and the ease of handling and separating byproducts from reaction mixtures. A one-pot process was developed by Song's group for the synthesis of 8-arylquinolines via Pd-catalyzed borylation of quinoline-8-yl halides and subsequent Suzuki-Miyaura coupling with aryl halides using n-BuPAd 2 as ligand. Yields of up to $98 \%$ were obtained [50].<smiles>CCCCP(CCCCCC(C)(C)C)C12CC3CC(CC(C3)C1)C2</smiles><smiles>COc1ccc(Br)c2c1=CCCN=2</smiles>

135<smiles>CC(C)(C)C(C)(C)OB1OC(C)(C)C(C)(C)O1</smiles>

136 $\underset{3.0 \text { eq. } \mathrm{KOAC}}{\frac{\mathrm{Pd}_{2}(\mathrm{dba})_{3} \text {, ligand }}{\text {. }}}$ solvent, $90^{\circ} \mathrm{C}$; aqueous workup<smiles>COc1ccc(B(O)O)c2cccnc12</smiles>

137<smiles>COc1cccc2nc[cH+]ccc12</smiles>

138<smiles>COc1ccc(-c2ccc(OC)c3cccnc23)c2ncccc12</smiles>

139

Scheme 39 Investigation was related with optimization of Pd-catalyzed borylation of electron-rich 8bromo-5-methoxyquinoline. Firstly, borylation with pinacol borane (PinB-H) was done under Buchwald's conditions [1.5 equiv PinB- $\mathrm{H}, 3 \mathrm{~mol} \% \mathrm{PdCl}_{2}-\left(\mathrm{CH}_{3} \mathrm{CN}\right)_{2}, 12 \mathrm{~mol} \%$ S-Phos, 3 equiv Net3, 1,4-dioxane $(0.6 \mathrm{~mL} / \mathrm{mmol}$ bromide)] [51]. The reaction gave the debromo compound 5methoxyquinoline as the only product. After that, borylation with bis(pinacolato)diboron was focused. As observed on LC-MS, the borylation product was isolated as the boronic acid instead of the pinacol boronate. Experimental results were summarized in Table 2. 
Table 2. Optimization of Reaction Conditions for Borylation of 8-Bromo-5-methoxy Quinoline with Bis(pinacolato)diboron

\begin{tabular}{|c|c|c|c|c|c|c|}
\hline Entry & Ligand & mol\% ligand & $\mathrm{Pd}: \mathrm{L}$ & solvent & time(h) & yield of $137(\%)^{d}$ \\
\hline 1 & $\mathrm{dppf}^{\mathrm{b}}$ & 3 & & 1,4-dioxane & 12 & 68 \\
\hline 2 & $\mathrm{dpp} \mathrm{f}^{\mathrm{b}}$ & 3 & & DMAc & 5 & 33 \\
\hline 3 & $\mathrm{Pd}\left(\mathrm{PPh}_{3}\right)_{4}$ & 6 & & 1,4-dioxane & 20 & 72 \\
\hline 4 & S-Phos & 2 & $1: 4.0$ & 1,4-dioxane & 5 & 66 \\
\hline 5 & S-Phos & 2 & $1: 1.5$ & DMAc & 6 & 70 \\
\hline 6 & X-Phos & 2 & $1: 1.5$ & DMAc & 7 & 69 \\
\hline 7 & BI-DIME & 2 & $1: 1.5$ & DMAc & 10 & 10 \\
\hline 8 & $\mathrm{t}-\mathrm{Bu} \mathrm{P}_{\mathrm{Pc}}$ & 2 & & DMAc & 1 & 60 \\
\hline 9 & Суз $\mathrm{P}$ & 2 & $1: 1.5$ & DMAc & 2 & 77 \\
\hline 10 & n-BuPAd 2 & 2 & $1: 1.5$ & 1,4-dioxane & 2 & 88 \\
\hline 11 & n-BuPAd 2 & 2 & $1: 1.5$ & DMSO & 2 & 88 \\
\hline 12 & n-BuPAd 2 & 2 & $1: 1.5$ & DMF & 1 & 90 \\
\hline 13 & n-BuPAd 2 & 2 & $1: 1.5$ & DMAc & 1 & $93(88 \%)^{\mathrm{e}}$ \\
\hline 14 & n-BuPAd 2 & 2 & $1: 1.5$ & NMP & 1 & 83 \\
\hline
\end{tabular}

${ }^{a}$ Reaction conditions: 8-bromo-5-methoxy quinoline (0.2 g, $\left.0.84 \mathrm{mmol}\right), 2$ (1.09 mmol), palladium catalyst (1-6 mol \%), ligand, potassium acetate $(2.52 \mathrm{mmol})$, solvent $(1 \mathrm{~mL}), 90{ }^{\circ} \mathrm{C}$, under $\mathrm{N}_{2}$ atmosphere. Water was added to the reaction mixture after the reaction time indicated in the table. ${ }^{b} \mathrm{Pd}(\mathrm{dppf}) \mathrm{Cl}_{2} . \mathrm{CH}_{2} \mathrm{Cl}_{2}$ was used. ${ }^{c} \mathrm{Di}$ - $\mu$-bromobis(tri-tert-butylphosphino)dipalladium(I) was used. ${ }^{d}$ Yield determined by HPLC. ${ }^{e}$ Number in parentheses refers to isolated yield.

The pyridazine nucleus and its 3-oxo derivative pyridazinones are recognized as versatile scaffolds with a wide range of biological activities that can also be utilized to support other pharmacophoric groups. Herein, the reported results lead to an efficient synthetic route from which a large number of analogues with variable substitutions at the N-2, C-5, and C-6 positions of the pyridazinone ring. As depicted in Scheme 40, synthesis employs a very efficient microwave (MW) promoted SuzukiMiyaura cross coupling between 6-chloro-5-dialkylaminopyridazinones $\mathbf{1 4 0}$ and arylboronic acids as the key transformation in the preparation of 6-aryl-5-dialkylamino-(2H)-pyridazin-3-one 141 [52].<smiles>[R]N([R2])c1cc(=O)n([R3])nc1Cl</smiles>

\section{Scheme 40}

This method can be served as an attractive tool since it adds the aryl group toward the end of the synthesis, which allows to add a wide range of commercially available boronic acids. The scope and limitation of using a palladium complex mixture as catalyst was also investigated. The activity of the individual catalysts (PXPd, POPd, PXPd2, POPd2, PXPd6, and POPd6) consisting of Combiphos Pd6 was examined for Suzuki coupling between 1-benzyl-6-chloro-5-piperidyl-(2H)-pyridazin-3-one (1a) and phenylboronic acid. The results are summarized in Table 3. 
Table 3: Comparison of Catalyst Systems for Palladium-Catalyzed Suzuki Coupling of 6Chloropyridazinone
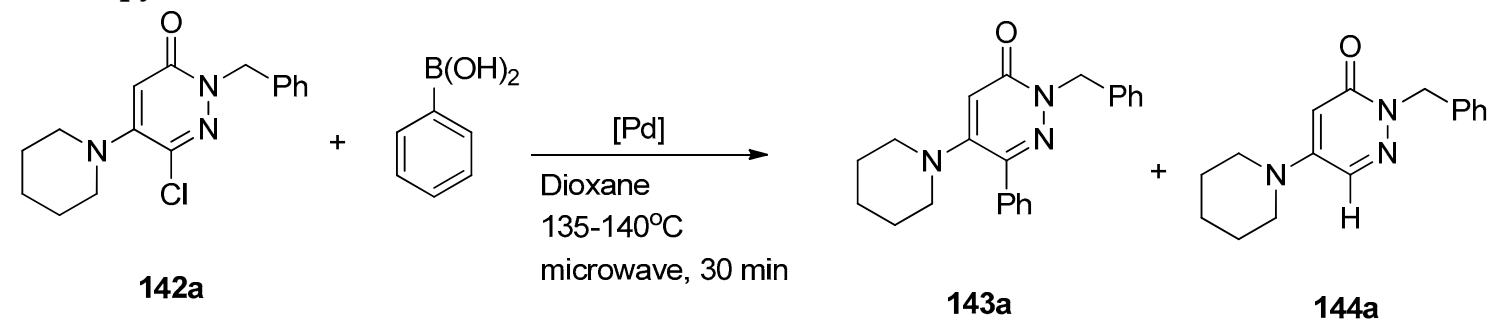

Scheme 41

Table 3

\begin{tabular}{|c|c|c|c|c|}
\hline Entry & {$[\mathrm{Pd}](5 \mathrm{~mol} \%)$} & base+solvent & product $(\%) b$ & $\begin{array}{l}\text { byproduct } \\
\mathbf{1 4 4 a}(\%)\end{array}$ \\
\hline 1 & Pd6 & $\mathrm{Cs}_{2} \mathrm{CO}_{3} /$ dioxane & 77 & 13 \\
\hline 2 & POPD2 & $\mathrm{Cs}_{2} \mathrm{CO}_{3} /$ dioxane & 44 & 14 \\
\hline 3 & PXPd2 & $\mathrm{Cs}_{2} \mathrm{CO}_{3} /$ dioxane & 88 & 12 \\
\hline 4 & PXPd2 & $\mathrm{Cs}_{2} \mathrm{CO}_{3} /$ dioxane & 88 & 12 \\
\hline 5 & POPd6 & $\mathrm{Cs}_{2} \mathrm{CO}_{3} /$ dioxane & 55 & 21 \\
\hline 6 & PXPd6 & $\mathrm{Cs}_{2} \mathrm{CO}_{3} /$ dioxane & 84 & 16 \\
\hline 7 & $\mathrm{Pd}_{2}(\mathrm{dba})_{3} / \mathrm{PPh}_{3}$ & $\mathrm{Cs}_{2} \mathrm{CO}_{3} /$ dioxane & 90 & 10 \\
\hline 8 & $\mathrm{Pd}_{2}(\mathrm{dba})_{3} /$ xanthphos & $\mathrm{Cs}_{2} \mathrm{CO}_{3} /$ dioxane & 43 & 12 \\
\hline 9 & $\mathrm{Pd}_{2}(\mathrm{dba})_{3} / \mathrm{dppf}$ & $\mathrm{Cs}_{2} \mathrm{CO}_{3} /$ dioxane & 50 & 10 \\
\hline 10 & $\mathrm{Pd}_{2}(\mathrm{dba})_{3} / \mathrm{SPHOS}$ & $\mathrm{Cs}_{2} \mathrm{CO}_{3} /$ dioxane & 97 & 3 \\
\hline 11 & $\mathrm{Pd}_{2}(\mathrm{dba})_{3} / \mathrm{SPHOS}$ & $\mathrm{Cs}_{2} \mathrm{CO}_{3} / \mathrm{THF}$ & 64 & 36 \\
\hline 12 & Pd2(dba)3/SPHOS & $\mathrm{Cs}_{2} \mathrm{CO}_{3} / \mathrm{DMF}$ & 97 & 3 \\
\hline 13 & $\mathrm{Pd}_{2}(\mathrm{dba})_{3} / \mathrm{SPHOS}$ & $\mathrm{Cs}_{2} \mathrm{CO}_{3} /$ toluene & 48 & 42 \\
\hline 14 & $\mathrm{Pd}_{2}(\mathrm{dba})_{3} / \mathrm{SPHOS}$ & $\mathrm{K}_{2} \mathrm{CO}_{3} /$ dioxane & 30 & 0 \\
\hline 15 & Pd6 & $\mathrm{K}_{2} \mathrm{CO}_{3} /$ dioxane & 93 & 7 \\
\hline 16 & $\mathrm{Pd}_{2}(\mathrm{dba})_{3} / \mathrm{SPHOS}$ & $\mathrm{K}_{2} \mathrm{CO}_{3} /$ dioxane & 83 & 1 \\
\hline 17 & $\mathrm{Pd}_{2}(\mathrm{dba})_{3} / \mathrm{SPHOS}$ & KF/dioxane & 100 & 0 \\
\hline 18 & $\mathrm{Pd}_{2}(\mathrm{dba})_{3} / \mathrm{SPHOS}$ & $\mathrm{KOH} /$ dioxane & 49 & 5 \\
\hline 19 & $\mathrm{Pd}_{2}(\mathrm{dba})_{3} / \mathrm{SPHOS}$ & CsF/dioxane & 50 & 2 \\
\hline 20 & $\mathrm{Pd}_{2}(\mathrm{dba})_{3} / \mathrm{SPHOS}$ & KF/DMF & 100 & 0 \\
\hline
\end{tabular}

The 2-pyrazoline ring system has attracted significant interest in organic and medicinal chemistry over the past several decades. Scaffolds containing the 2-pyrazoline (4,5-dihydropyrazole) heterocycle have demonstrated a wide range of biological activity, including anticancer activity through the inhibition of kinesin spindle protein, CB1 receptor antagonism for obesity, monoamine oxidase inhibition for depression and a host of other antibacterial, antiviral, and anti-inflammatory activities. The efficient Suzuki cross-coupling of pyrazoline nonaflates with organoboron reagents was achieved to afford diverse 3-substituted-2-pyrazolines in excellent yield. The nonaflates 
displayed improved reactivity over the corresponding triflates and smoothly coupled to a variety of aryl- and heteroarylboronic acids. This process and its broad scope constitute a rapid, divergent strategy for the synthesis of elaborated 2-pyrazolines that are not readily obtained via conventional methods [53].

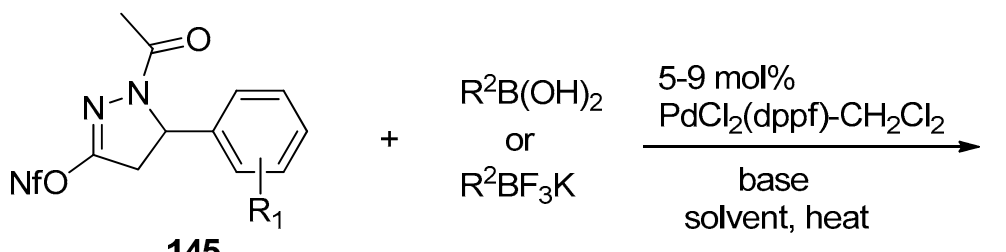

145

$\mathrm{R}^{2}=$ aryl, heteroaryl, alkenyl, alkyl<smiles>[R]C1=NN(C(C)=O)C(c2ccccc2)C1</smiles>

146

Scheme 42 The Suzuki cross-coupling of 3-sulfonyloxy-2-pyrazolines was of particular interest due to the extensive availability and synthetic accessibility of organoboron reagents. Such a process would provide rapid access to 3 heteroarylpyrazolines and allow incorporation of heterocycles commonly seen in medicinal chemistry (Scheme 43).<smiles>[R]OC1=NN(C(C)=O)C(C2=CCC=CC2)C1</smiles>

147<smiles>[O+]c1cccnc1</smiles>

148<smiles>CC(=O)N1N=C(c2cccnc2)CC1c1ccccc1</smiles>

149

Scheme 43 Aryl and hetaroaryl imidazole-1-sulfonates are efficiently arylated and alkenylated with aryl- and alkenylboronic acids and potassium trifluoroborates by using 0.5 mol-\% palladacycles 151 or $\mathrm{Pd}(\mathrm{OAc})_{2}$ at $110{ }^{\circ} \mathrm{C}$ under aqueous and phosphane- free conditions. Reactions can be performed by using conventional or microwave heating, leading to biaryls, stilbenes, and alkenylarenes in good to high yields, and high regio- and diastereoselectivities. The optimized methodology allows in situ phenol sulfonylation and one-pot Suzuki arylation or alkenylation as well as orthogonal functionalization of halogen-containing aryl imidazolesulfonates.<smiles>[R2]c1ccc2c([R1])n[R](Cl)(Cl)c2c1</smiles>

151

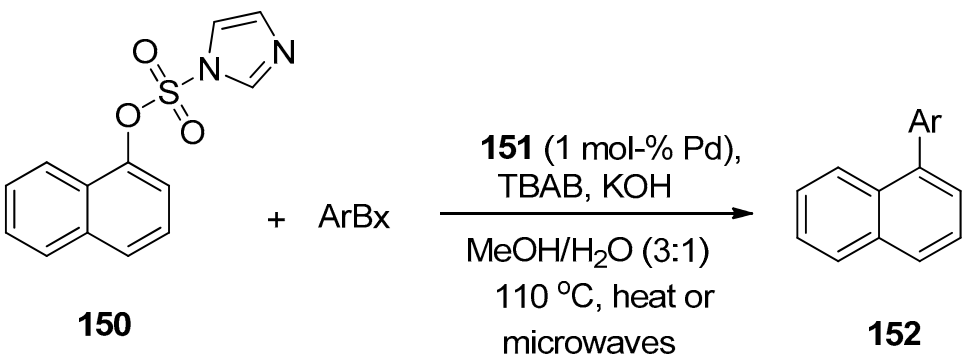

Scheme 44 In present days, the synthesis of new and safe therapeutic agents is getting high importance in the field of medicinal science and pharmaceuticals. Most precisely, sulphur containing heterocycles have gained much importance in this field. It is seen that the regioselective functionalizations of halogenated heterocycles play an important role in the synthesis of several types of organic compounds. For this, the Suzuki-Miyaura reaction has emerged as a convenient way to 
build carbon-carbon bonds in synthesizing organic compounds. Some of the most important applications of these reactions can be seen in the synthesis of natural products, and in designing targeted pharmaceutical compounds. Herein, the regioselective synthesis of the novel series of 2(bromomethyl) 5-aryl-thiophenes 156, via Suzuki cross-coupling reactions of various aryl boronic acids with 2-bromo-5-(bromomethyl)thiophene 155 is reported (Scheme 45) [54].<smiles>Cc1cccs1</smiles>

154

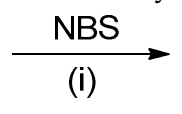

(i)<smiles>BrCc1ccc(Br)s1</smiles>

155

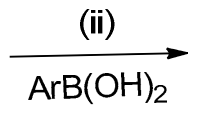

$\operatorname{ArB}(\mathrm{OH})_{2}$<smiles>BrCc1ccc(Br)s1</smiles>

156

Scheme 45: Synthesis of intermediate compound 2-bromo-5-(bromomethyl)thiophene (155) and 2(bromomethyl)-5-arylthiophenes(156).

Conditions: i, 154, (1 eq, $20.4 \mathrm{mmol})$, NBS (2.1 eq, $42.84 \mathrm{mmol}), \mathrm{CCl} 4$ (9-10 mL). Procedure: reflux 154 and NBS in $\mathrm{CCl}_{4}$ for 4-5 hours; Condition ii, 155 (1 eq, $\left.0.976 \mathrm{mmol}\right), \mathrm{Pd}\left(\mathrm{PPh}_{3}\right)_{4}(2.5 \mathrm{~mol} \%)$ aryl boronic acid (1.1 eq, $1.073 \mathrm{mmol}), \mathrm{K}_{3} \mathrm{PO}_{4}$ (2 eq, 1x.952 mmol), 1,4-dioxane $/ \mathrm{H}_{2} \mathrm{O}(4: 1), 12 \mathrm{~h}, 90^{\circ} \mathrm{C}$.

The Suzuki cross coupling reaction has a great deal of importance in the synthesis of substituted aromatic compounds of biological importance. The relatively easy formation of C-C bonds via Suzuki cross coupling reaction may have its origin in the high tolerance of functional group through this reaction pathway [55]. Many heterocycles such as arylated furans and thiophenes have been synthesized in high yield using this reaction scheme [56]. Being versatile in nature and demonstrating compatibility with functional groups, the Suzuki cross coupling reaction is the method of choice for reactions involving $\mathrm{C}-\mathrm{C}$ bond formation [57]. In present study, a convenient approach for the synthesis of thiophene sulfonamide derivatives 159 via Suzuki cross coupling reaction is reported. This method of synthesis involved the reactions of various aryl boronic acids and esters with 5bromthiophene-2-sulfonamide 158 under mild and suitable temperature conditions (scheme 46). The antibacterial and hemolytic activities of the derivatives of 5-arylthiophene-2-sulfonamide and 5bromothiophene-2-acetamide were also investigated during the course of the study [58].<smiles>Brc1cccs1</smiles>

157

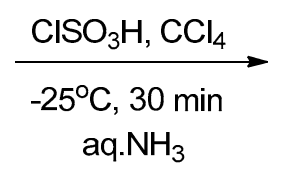

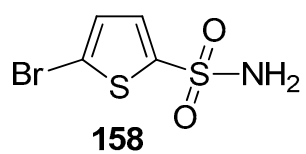

158
Aryl Boronic acids

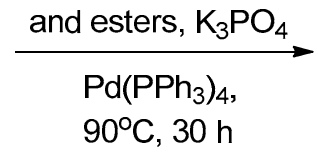

$90^{\circ} \mathrm{C}, 30 \mathrm{~h}$<smiles>NS(=O)(=O)c1ccc([Al])s1</smiles>

159<smiles>CC(=O)NS(=O)(=O)c1ccc(Br)s1</smiles>

160

Scheme 46: Synthesis of 5-Bromothiophene-2-sulfonamide (158) and 5-arylthiophene sulfonamide

Nowadays the benzothiazole moiety has great scientific importance as it is a weak base heterocyclic compound having numerous biological activities. Benzothiazoles are mostly found in medicinal and bio-organic chemistry, with multiple applications in drug discovery. In general, benzothiazole derivatives have attracted great interest due to their pharmaceutical and biological importance. New 
2-amino-6-arylbenzothiazoles were synthesized in moderate to excellent yields via Suzuki cross coupling reactions using various aryl boronic acids and aryl boronic acid pinacol esters. For the synthesis of biaryl systems the palladium-catalyzed Suzuki cross coupling reaction represents one of the best methods [59]. Majo and coworkers reported Suzuki cross coupling reactions of 2bromobenzothiazole with aryl boronic acids to provide the corresponding 2-arylbenzothiazole compounds. Suzuki cross coupling reactions of 2-amino-6-bromobenzothiazole 162 with various aryl boronic acids and esters under optimized heating conditions was investigated. (Scheme 47)

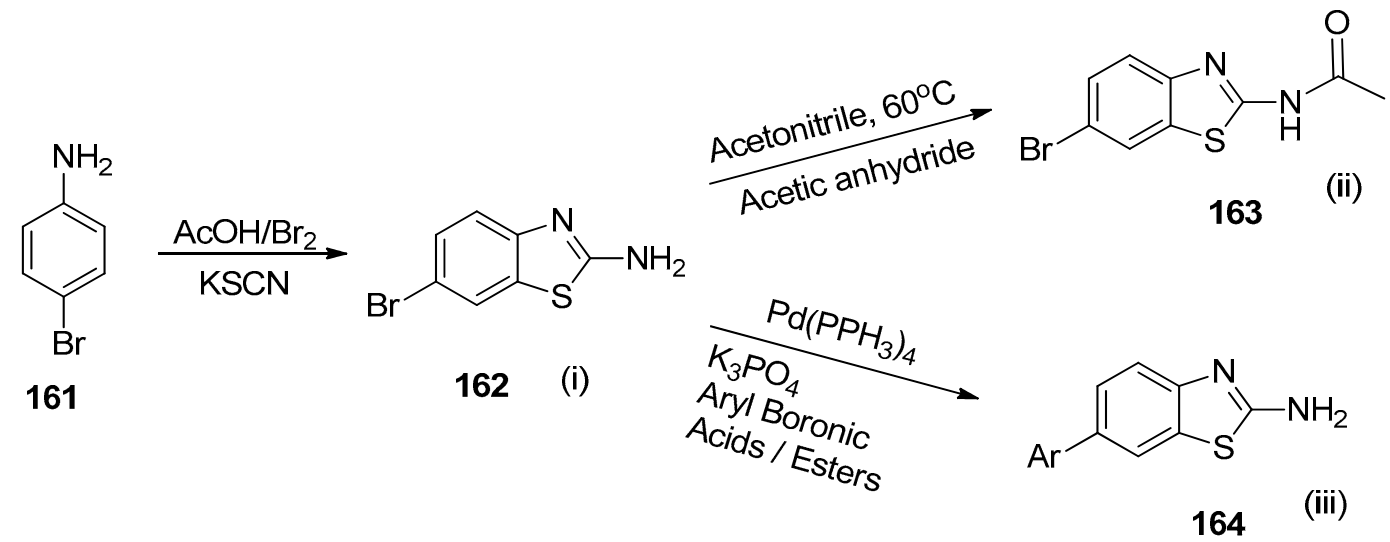

Scheme 47. Synthesis of Benzothiazoles (1) Synthesis of 2-amino-6-bromobenzothiazole (162), Synthesis of $N$-(6-bromobenzo[d]thiazol-2-yl)acetamide

(163) and 2-amino-6-arylbenzothiazole (164). Reagents and conditions: (i): 161 (0.011 mol), acetic acid $(0.011 \mathrm{~mol})$, potassium thiocynate $(0.044 \mathrm{~mol})$, bromine $(0.011 \mathrm{~mol})$; (ii) $162(0.002 \mathrm{~mol})$, acetic anhydride

(0.0031 mol), acetonitrile ( $5 \mathrm{ml})$; (iii) 162 (2.183 mmol), aryl boronic acids and aryl boronic acid pinacol esters

(2.401 mmol), $\mathrm{K}_{3} \mathrm{PO}_{4}(4.3 \mathrm{mmol}), \mathrm{Pd}\left(\mathrm{PPh}_{3}\right)_{4}(5 \mathrm{~mol} \%)$, solvent / $\mathrm{H}_{2} \mathrm{O}(4: 1), 95^{\circ} \mathrm{C}, 31 \mathrm{~h}$.

There is a very little work on the synthesis of 2-amino-6-aryl benzothiazoles 164 so far and limited information has been published on the urease enzyme inhibition and NO scavenging activities of 2amino-6-arylbenzothiazole derivatives. 2-Amino-6-bromobenzothiazole 162 was prepared stirring by 4-bromoaniline with acetic acid $(0.011 \mathrm{~mol})$ and potassium thiocynate $(0.044 \mathrm{~mol})$ in solution of bromine (0.011 mol) in $\mathrm{AcOH}(7 \mathrm{~mL})$ at room temperature (Scheme 48) [60].

\section{Conclusions}

This review shows that the Suzuki Miyaura cross-coupling is more user-friendly than other coupling reactions and is widely used in the synthesis of various natural and non-natural products. Several drug-like molecules can also be synthesized by using this remarkable coupling reaction. Suzuki Coupling is advance and can be conducted in almost all mild conditions. Limited examples are available regarding the asymmetric SM cross-coupling reaction and it is hoped that more advances may come in the near future.

Acknowledgments: The authors gratefully acknowledge the financial support by HEC (HEC Project No. $20-1465 / R \& D / 09 / 5458)$. We are also thankful to University of Malaysia Pahang for grant number RDU150349 and 150109

Author Contributions: S.K. H.I. N.R. conceived the outline the review; G.A. M.N.A. and N.B.A. selected the materials. All authors wrote the paper with equally contributed. 
Conflicts of Interest: The authors declare no conflict of interest.

\section{References}

1. Suzuki, A., Recent advances in the cross-coupling reactions of organoboron derivatives with organic electrophiles, 1995-1998. Journal of Organometallic Chemistry 1999, 576, 147-168.

2. Giri, R.; Maugel, N.; Li, J.-J.; Wang, D.-H.; Breazzano, S. P.; Saunders, L. B.; Yu, J.-Q., Palladium-Catalyzed Methylation and Arylation of $\mathrm{sp}^{2}$ and $\mathrm{sp}^{3} \mathrm{C}-\mathrm{H}$ Bonds in Simple Carboxylic Acids. Journal of the American Chemical Society 2007, 129, 3510-3511.

3. Jung, D.; Shimogawa, H.; Kwon, Y.; Mao, Q.; Sato, S.-i.; Kamisuki, S.; Kigoshi, H.; Uesugi, M., Wrenchnolol derivative optimized for gene activation in cells. Journal of the American Chemical Society 2009, 131, 4774-4782.

4. Grasa, G. A.; Viciu, M. S.; Huang, J.; Zhang, C.; Trudell, M. L.; Nolan, S. P., Suzuki-Miyaura Cross-Coupling Reactions Mediated by Palladium/Imidazolium Salt Systems. Organometallics 2002, 21, 2866-2873.

5. Brossard, D.; El Kihel, L.; Khalid, M.; Rault, S., Synthesis of 6-aryl-substituted cholesterol derivatives from $3 \beta$-acetoxy-6-iodocholest-5-ene and arylboronic acids promoted by palladium-catalyzed cross-coupling. Synlett 2010, 2010, 215-218.

6. Richardson, T. I.; Clarke, C. A.; Yu, K.-L.; Yee, Y. K.; Bleisch, T. J.; Lopez, J. E.; Jones, S. A.; Hughes, N. E.; Muehl, B. S.; Lugar, C. W., Novel 3-aryl indoles as progesterone receptor antagonists for uterine fibroids. ACS Medicinal Chemistry Letters 2010, 2, 148-153.

7. Winne, J. M.; Guang, B.; D'herd, J.; De Clercq, P. J., Application of the B-Alkyl SuzukiMiyaura Cross-Coupling Reaction to the Stereoselective Synthesis of Analogues of (3 S)Oxidosqualene. Organic Letters 2006, 8, 4815-4818.

8. Valente, S.; Bana, E.; Viry, E.; Bagrel, D.; Kirsch, G., Synthesis and biological evaluation of novel coumarin-based inhibitors of Cdc25 phosphatases. Bioorganic \& Medicinal Chemistry Letters 2010, 20, 5827-5830.

9. Kotha, S.; Lahiri, K.; Kashinath, D., Recent applications of the Suzuki-Miyaura crosscoupling reaction in organic synthesis. Tetrahedron 2002, 58, 9633-9695.

10. Kimura, M.; Shiba, T.; Muto, T.; Hanabusa, K.; Shirai, H., Energy transfer within rutheniumcored rigid metallodendrimers. Tetrahedron Letters 2000, 41, 6809-6813.

11. Collet, S.; Danion-Bougot, R.; Danion, D., Suzuki Cross-Coupling Reactions Of Nonracemic Vinylborono-A-Amino Acids. Synthetic Communications 2001, 31, 249-255.

12. Kotha, S.; Halder, S.; Lahiri, K., Modification of indane-based unusual $\alpha$-amino acid derivatives via the Suzuki-Miyaura coupling reaction. Synthesis 2002, 2002, 0339-0342.

13. Iglesias, B.; Alvarez, R.; de Lera, A. R., A general synthesis of alkylpyridines. Tetrahedron 2001, 57, 3125-3130.

14. Gonzalez, D.; Martinot, T.; Hudlicky, T., A short chemoenzymatic synthesis of (+)narciclasine. Tetrahedron Letters 1999, 40, 3077-3080.

15. Pridgen, L. N.; Huang, G. K., An optimized palladium catalyzed cross-coupling of nonracemic trifluoromethylsulfonyl and fluorosulfonyl enol ethers to arylboronic acids. Tetrahedron Letters 1998, 39, 8421-8424.

16. Ma, D.; Wu, Q., Synthesis of the biaryl moiety of the proteasome inhibitors TMC-95 via a ligandless Pd (OAc) 2-catalyzed Suzuki-coupling reaction. Tetrahedron Letters 2001, 42, 52795281.

17. Link, J.; Sorensen, B. K., A method for preparing C-glycosides related to phlorizin. Tetrahedron Letters 2000, 41, 9213-9217.

18. Gooßen, L. J., Pd-catalyzed synthesis of arylacetic acid derivatives from boronic acidsDedicated to Professor KB Sharpless on the occasion of his 60th birthday. Chemical Communications 2001, 669-670. 
19. Mphahlele, M. J.; Mphahlele, M. M., One-pot palladium-catalyzed CeI and CeH bond activation and subsequent SuzukieMiyaura cross-coupling of 2-aryl-3-iodo-4(phenylamino)quinolines with arylboronic acids. Tetrahedron 2011, 67, 4689-4695.

20. Li, Z.; Ma, L.; Tang, C.; Xu, J.; Wu, X.; Yao, H., Palladium (II)-catalyzed oxidative Heck coupling of thiazole-4-carboxylates. Tetrahedron Letters 2011, 52, 5643-5647.

21. Lacy, A.; O'kennedy, R., Studies on coumarins and coumarin-related compounds to determine their therapeutic role in the treatment of cancer. Current Pharmaceutical Design 2004, 10, 3797-3811.

22. Garazd, M.; Garazd, Y. L.; Khilya, V., Neoflavones. 1. Natural distribution and spectral and biological properties. Chemistry of Natural Compounds 2003, 39, 54-121.

23. Wu, J.; Liao, Y.; Yang, Z., Synthesis of 4-substituted coumarins via the palladium-catalyzed cross-couplings of 4-tosylcoumarins with terminal acetylenes and organozinc reagents. The Journal of Organic Chemistry 2001, 66, 3642-3645.

24. Khoobi, M.; Molaverdi, F.; Jafarpour, F.; Abbasnia, M.; Kubicki, M.; Shafiee, A., A one-pot domino $\mathrm{C}-\mathrm{H}, \mathrm{C}-\mathrm{C}$ activation in coumarins: a fast track to 2, 3-diaryl benzo [b] furans. Chemical Communications 2015, 51, 11713-11716.

25. Ganina, O.; Veselov, I.; Grishina, G.; Fedorov, A. Y.; Beletskaya, I., Synthesis of 4aminopolymethoxycoumarins from 4-hydroxycoumarin triflates. Russian Chemical Bulletin 2006, 55, 1642-1647.

26. Li, Y.; Qi, Z.; Wang, H.; Fu, X.; Duan, C., Palladium-catalyzed oxidative Heck coupling reaction for direct synthesis of 4-arylcoumarins using coumarins and arylboronic acids. The Journal of Organic Chemistry 2012, 77, 2053-2057.

27. Rajale, T.; Sharma, S.; Stroud, D. A.; Unruh, D. K.; Miaou, E.; Lai, K.; Birney, D. M., An efficient synthesis of 4-substituted coumarin derivatives via a palladium-catalyzed Suzuki cross-coupling reaction. Tetrahedron Letters 2014, 55, 6627-6630.

28. Bariamis, S. E.; Marin, M.; Athanassopoulos, C. M.; Kontogiorgis, C.; Tsimali, Z.; Papaioannou, D.; Sindona, G.; Romeo, G.; Avgoustakis, K.; Hadjipavlou-Litina, D., Syntheses and evaluation of the antioxidant activity of novel methoxypsoralen derivatives. European Journal of Medicinal Chemistry 2013, 60, 155-169.

29. Eleya, N.; Malik, I.; Reimann, S.; Wittler, K.; Hein, M.; Patonay, T.; Villinger, A.; Ludwig, R.; Langer, P., Efficient Synthesis of Arylated Flavones by Site-Selective Suzuki-Miyaura CrossCoupling Reactions of the Bis (triflate) of 5, 7-and 7, 8-Dihydroxyflavone. European Journal of Organic Chemistry 2012, 2012, 1639-1652.

30. Schnürch, M.; Flasik, R.; Khan, A. F.; Spina, M.; Mihovilovic, M. D.; Stanetty, P., CrossCoupling Reactions on Azoles with Two and More Heteroatoms. European Journal of Organic Chemistry 2006, 2006, 3283-3307.

31. Nonell, S.; Borrell, J. I.; Borrós, S.; Colominas, C.; Rey, O.; Rubio, N.; Sánchez-García, D.; Teixidó, J., 2,7,12,17-Tetra (p-butylphenyl)-3,6,13,16-tetraazaporphycene: The First Example of a Straightforward Synthetic Approach to a New Class of Photosensitizing Macrocycles. European Journal of Organic Chemistry 2003, 2003, 1635-1640.

32. Srinivasan, A.; Rajashekar, K.; Shyamapada, B.; Syam Kumar, U., Facile and Simple Synthesis of N-Alkyl and N-Aryl 2-Benzazepines by Nucleophilic Heteroannulation. Synthetic Communications 2014, 44, 3112-3121.

33. El Bouakher, A.; Allouchi, H.; Abrunhosa-Thomas, I.; Troin, Y.; Guillaumet, G., SuzukiMiyaura Reactions of Halospirooxindole Derivatives. European Journal of Organic Chemistry 2015, 2015, 3450-3461.

34. El Bouakher, A.; Massip, S.; Jarry, C.; Troin, Y.; Abrunhosa-Thomas, I.; Guillaumet, G., A General and Efficient Method to Access Tetracyclic Spirooxindole Derivatives. European Journal of Organic Chemistry 2015, 2015, 556-569.

35. Koubachi, J.; El Kazzouli, S.; Bousmina, M.; Guillaumet, G., Functionalization of Imidazo [1,2a] pyridines by Means of Metal-Catalyzed Cross-Coupling Reactions. European Journal of Organic Chemistry 2014, 2014, 5119-5138. 
36. Enguehard, C.; Renou, J.-L.; Collot, V.; Hervet, M.; Rault, S.; Gueiffier, A., Reactivity of 3iodoimidazo [1,2-a] pyridines using a Suzuki-type cross-coupling reaction. The Journal of Organic Chemistry 2000, 65, 6572-6575.

37. Humphries, A. C.; Gancia, E.; Gilligan, M. T.; Goodacre, S.; Hallett, D.; Merchant, K. J.; Thomas, S. R., 8-Fluoroimidazo [1,2-a] pyridine: synthesis, physicochemical properties and evaluation as a bioisosteric replacement for imidazo [1,2-a] pyrimidine in an allosteric modulator ligand of the GABAA receptor. Bioorganic \& Medicinal Chemistry Letters 2006, 16, 1518-1522.

38. Goodacre, S. C.; Street, L. J.; Hallett, D. J.; Crawforth, J. M.; Kelly, S.; Owens, A. P.; Blackaby, W. P.; Lewis, R. T.; Stanley, J.; Smith, A. J., Imidazo [1,2-a] pyrimidines as functionally selective and orally bioavailable GABAA $\alpha 2 / \alpha 3$ binding site agonists for the treatment of anxiety disorders. Journal of Medicinal Chemistry 2006, 49, 35-38.

39. Kabri, Y.; Crozet, M. D.; Primas, N.; Vanelle, P., One-Pot Chemoselective Bis (SuzukiMiyaura Cross-Coupling): Efficient Access to 3,9-Bis [(hetero) aryl]-4H-pyrido [1,2-a] pyrimidin-4-one Derivatives Under Microwave Irradiation. European Journal of Organic Chemistry 2012, 2012, 5595-5604.

40. Chen, L.; Lang, H.; Fang, L.; Yu, J.; Wang, L., Nickel-Catalyzed Desulfitative Suzuki-Miyaura Cross-Coupling of N, N-Disulfonylmethylamines and Arylboronic Acids. European Journal of Organic Chemistry 2014, 2014, 6385-6389.

41. Kim, J. Y.; Lee, J. W.; Lee, W. S.; Ha, H.-H.; Vendrell, M.; Bork, J. T.; Lee, Y.; Chang, Y.-T., Combinatorial solid-phase synthesis of 4,6-diaryl and 4-aryl, 6-alkyl-1,3,5-triazines and their application to efficient biofuel production. ACS Combinatorial Science 2012, 14, 395-398.

42. Romagnoli, R.; Baraldi, P. G.; Pavani, M. G.; Tabrizi, M. A.; Preti, D.; Fruttarolo, F.; Piccagli, L.; Jung, M. K.; Hamel, E.; Borgatti, M., Synthesis and biological evaluation of 2-amino-3$\left(3^{\prime}, 4^{\prime}, 5^{\prime}\right.$-trimethoxybenzoyl)-5-aryl thiophenes as a new class of potent antitubulin agents. Journal of Medicinal Chemistry 2006, 49, 3906-3915.

43. Weggen, S.; Eriksen, J. L.; Das, P.; Sagi, S. A.; Wang, R.; Pietrzik, C. U.; Findlay, K. A.; Smith, T. E.; Murphy, M. P.; Bulter, T., A subset of NSAIDs lower amyloidogenic A $\beta 42$ independently of cyclooxygenase activity. Nature 2001, 414, 212-216.

44. Eriksen, J. L.; Sagi, S. A.; Smith, T. E.; Weggen, S.; Das, P.; McLendon, D.; Ozols, V. V.; Jessing, K. W.; Zavitz, K. H.; Koo, E. H., NSAIDs and enantiomers of flurbiprofen target $\gamma$-secretase and lower A $\beta 42$ in vivo. The Journal of Clinical Investigation 2003, 112, 440-449.

45. Gasparini, L.; Rusconi, L.; Xu, H.; Del Soldato, P.; Ongini, E., Modulation of $\beta$-amyloid metabolism by non-steroidal anti-inflammatory drugs in neuronal cell cultures. Journal of Neurochemistry 2004, 88, 337-348.

46. Peretto, I.; Radaelli, S.; Parini, C.; Zandi, M.; Raveglia, L. F.; Dondio, G.; Fontanella, L.; Misiano, P.; Bigogno, C.; Rizzi, A., Synthesis and biological activity of flurbiprofen analogues as selective inhibitors of $\beta$-amyloid,1-42 secretion. Journal of Medicinal Chemistry 2005, 48, 5705-5720.

47. Leadbeater, N. E.; Marco, M., Rapid and amenable Suzuki coupling reaction in water using microwave and conventional heating. The Journal of Organic Chemistry 2003, 68, 888-892.

48. Angell, R. M.; Atkinson, F. L.; Brown, M. J.; Chuang, T. T.; Christopher, J. A.; Cichy-Knight, M.; Dunn, A. K.; Hightower, K. E.; Malkakorpi, S.; Musgrave, J. R., N-(3-Cyano-4,5,6,7tetrahydro-1-benzothien-2-yl) amides as potent, selective, inhibitors of JNK2 and JNK3. Bioorganic E Medicinal Chemistry Letters 2007, 17, 1296-1301.

49. Kamenecka, T.; Jiang, R.; Song, X.; Duckett, D.; Chen, W.; Ling, Y. Y.; Habel, J.; Laughlin, J. D.; Chambers, J.; Figuera-Losada, M., Synthesis, biological evaluation, X-ray structure, and pharmacokinetics of aminopyrimidine c-jun-N-terminal kinase (JNK) inhibitors. Journal of Medicinal Chemistry 2009, 53, 419-431.

50. Zhang, Y.; Gao, J.; Li, W.; Lee, H.; Lu, B. Z.; Senanayake, C. H., Synthesis of 8-arylquinolines via one-pot Pd-catalyzed borylation of quinoline-8-yl halides and subsequent SuzukiMiyaura coupling. The Journal of Organic Chemistry 2011, 76, 6394-6400. 
51. Billingsley, K. L.; Buchwald, S. L., An improved system for the palladium-catalyzed borylation of aryl halides with pinacol borane. The Journal of Organic Chemistry 2008, 73, 55895591.

52. Cao, P.; Qu, J.; Burton, G.; Rivero, R. A., Facile Synthesis of 6-Aryl 5-N-Substituted Pyridazinones: Microwave-Assisted Suzuki- Miyaura Cross Coupling of 6Chloropyridazinones. The Journal of Organic Chemistry 2008, 73, 7204-7208.

53. Grimm, J. B.; Wilson, K. J.; Witter, D. J., A divergent approach to the synthesis of 3substituted-2-pyrazolines: Suzuki cross-coupling of 3-sulfonyloxy-2-pyrazolines. The Journal of Organic Chemistry 2009, 74, 6390-6393.

54. Rizwan, K.; Zubair, M.; Rasool, N.; Ali, S.; Zahoor, A. F.; Rana, U. A.; Khan, S. U.-D.; Shahid, M.; Zia-Ul-Haq, M.; Jaafar, H. Z., Regioselective synthesis of 2-(bromomethyl)-5-arylthiophene derivatives via palladium (0) catalyzed suzuki cross-coupling reactions: as antithrombotic and haemolytically active molecules. Chemistry Central Journal 2014, 8, 74.

55. Handy, S. T.; Mayi, D., Regioselective double Suzuki couplings of 4,5-dibromothiophene-2carboxaldehyde. Tetrahedron Letters 2007, 48, 8108-8110.

56. Hassan, J.; Sevignon, M.; Gozzi, C.; Schulz, E.; Lemaire, M., Aryl-aryl bond formation one century after the discovery of the Ullmann reaction. Chemical Reviews 2002, 102, 1359-1470.

57. Joshaghani, M.; Daryanavard, M.; Rafiee, E.; Nadri, S., Synthesis and applications of a new palladacycle as a high active catalyst in the Suzuki couplings. Journal of Organometallic Chemistry 2008, 693, 3135-3140.

58. Noreen, M.; Rasool, N.; Gull, Y.; Zahoor, A. F.; Yaqoob, A.; Kousar, S.; Zubair, M.; Bukhari, I. H.; Rana, U. A., A facile synthesis of new 5-aryl-thiophenes bearing sulfonamide moiety via Pd (0)-catalyzed Suzuki-Miyaura cross coupling reactions and 5-bromothiophene-2acetamide: As potent urease inhibitor, antibacterial agent and hemolytically active compounds. Journal of Saudi Chemical Society 2017, 21, S403-S414.

59. Bellina, F.; Carpita, A.; Rossi, R., Palladium catalysts for the Suzuki cross-coupling reaction: an overview of recent advances. Synthesis 2004, 2004, 2419-2440.

60. Gull, Y.; Rasool, N.; Noreen, M.; Nasim, F.-u.-H.; Yaqoob, A.; Kousar, S.; Rashid, U.; Bukhari, I. H.; Zubair, M.; Islam, M. S., Efficient synthesis of 2-amino-6-arylbenzothiazoles via Pd (0) Suzuki cross coupling reactions: potent urease enzyme inhibition and nitric oxide scavenging activities of the products. Molecules 2013, 18, 8845-8857. 